\title{
Bioactivities of Six Plant Essential Oils against some Isolated Microbes from an Archaeological Limestone Statue at the Saqqara Excavation
}

\author{
Neveen S. Geweely, ${ }^{a}$ Hala A. M. Afifi, ${ }^{b}$ Shehata A. AbdelRahim, ${ }^{c}$ Gamal M. I. Kamh, ${ }^{\text {d }}$ \\ Mona M. Soliman, ${ }^{\mathrm{a}}$ Mohamed AbdelSattar, ${ }^{\mathrm{e}}$ Hayssam M. Ali, ${ }^{\mathrm{f}}$ Mohammad Akrami, ${ }^{\mathrm{g}}$ and \\ Mohamed Z. M. Salem ${ }^{\text {h, }}$
}

\begin{abstract}
The effect of microbial activity on the deterioration of archaeological stone items is a worldwide issue, and conserving them with low-toxicity, ecologically benign and naturally biocides is a difficult undertaking. Molecular identification of the microbial communities from a deteriorated archaeological object (Ptahshepses stone statue) located from the Saqqara excavation, Giza, Egypt was recorded. Six essential oils (EOs) (black cumin, clove, geranium, lavender, lemongrass, and thyme) were tested for antimicrobial activity against six degrading fungal and bacterial species. Alternaria alternate, Aspergillus flavus, A. niger, Cladosporium halotolerans, Penicillium crustosum, and Trichoderma viride and three bacterial species, Pseudomonas protegens, P. putida, and Serratia odorifera, were isolated. Of the most effective EOs, thyme showed the highest inhibition percentage (143.4\%) against Serratia odorifera, followed by $P$. putida (135\%), and Pseudomonas protegens (131.5\%). Lemongrass and clove EOs had minimum inhibitory concentrations (MICs) ranging from $0.5 \mu \mathrm{L} / \mathrm{mL}$ to $2 \mu \mathrm{L} / \mathrm{mL}$ for all isolated deteriorated fungal and bacterial species, while the lowest efficiency EOs were lavender, geranium and black cumin. It can be concluded that thyme and lemongrass EOs have a potential use for protecting the Ptahshepses stone statue from microbial deterioration.
\end{abstract}

Keywords: Fungal species; Bacterial species; Antimicrobial activity; Essential oils; Microorganisms; Archaeological object; Excavation

Contact information: a: Department of Botany and Microbiology, Faculty of Science, Cairo University, Giza 12613 Egypt; b: Department of Conservation and Restoration, Faculty of Archaeology, Cairo University, Giza 12613 Egypt; c: Department of Conservation and Restoration, Faculty of Archaeology, Fayoum University, Faiyum Egypt; d: Department of Geology, Faculty of Science, Menoufia University, Menoufia Egypt; e: Meat Raheena area, Ministry of Antiquities, Giza Egypt; f: Botany and Microbiology Department, College of Science, King Saud University, P.O. Box 2455, Riyadh 11451 Saudi Arabia; g: Department of Engineering, University of Exeter, Exeter EX4 4QF United Kingdom; h: Forestry and Wood Technology Department, Faculty of Agriculture (El-Shatby), Alexandria University, Alexandria 21545 Egypt; *Corresponding author: zidan_forest@yahoo.com

\section{INTRODUCTION}

Many studies deal with the treatment and conservation of the archaeological objects from the Saqqara excavation region (Afifi et al. 2020). Archaeological objects made from stone are an important part of the cultural heritage of the world. The history of humanness has been related to the use of stone, especially limestone, which was used for art objects, monuments, buildings, and private tombs, in which the walls were covered with paintings and reliefs in the ancient civilization in Egypt (Bard 2005). Ancient Egypt was considered 
as the "stone state" because stone was the most utilized raw material during the several periods of Pharaonic Egypt (ElBaghdady et al. 2019).

The major biodeterioration agents of cultural heritage are fungal species, which are capable of colonizing, degrading, corroding, and changing a variety of materials that have been used through the centuries for the production of archaeological artifacts and monuments (Sterflinger 2010; Afifi 2012). Endolithic fungi live inside the pores and fissures of stone, while epilithic fungi grow on the rock, mortar, building stone, and plaster due to their higher activity (Scheerer et al. 2009; Sterflinger 2010). Several fungal species can cause staining of different colors and sizes, which are difficult to remove, as the fungal hyphae not only grows on the surface but also within the object (Strzelczyk 2004). For example, fungal deterioration aspects have been observed for an archaeological limestone relief panel in the Koom Oshem museum, El-Fayoum, Egypt, where Alternaria alternate was the most dominant species in the limestone relief followed by Penicillium chrysogenum (Afifi and Geweely 2006).

In addition, a majority of bacteria secrete some enzymes and secondary metabolite products to break down different organic substrates (Boer et al. 2005; Netzker et al. 2015; Zeilinger et al. 2016). ElBaghdady et al. (2019) stated that halotolerant bacteria (Arthrobacter spp., Micrococcus spp., Bacillus spp., and Staphylococcus spp.) were noticeable stone degrading isolates, while Streptomyces sp. was the primary agent causing color change in tomb paintings by producing different acids, e.g., citric, oxalic, and succinic acid, as well as hydrogen sulfide and pigments. The chemical activity of biocides also affects treated materials (Agarossi et al. 1990). Gaseous fumigants can cause oxidization or polymerization, as well as corrosion of the treated materials (Daniels 1989; Soffritti et al. 2019). Chlorinated molecules can cause brittleness and discoloration of the treated ancient materials (Lee 2004). In addition, the thick and melanized cell walls of the fungi make them resistant to chemical attack and make them difficult to destroy with biocides or other antimicrobial treatments; black fungi settle deep within the granite, marble, and calcareous limestone, causing the stones to deteriorate (Sterflinger 2010).

Natural and environmentally-friendly alternatives, which show negligible toxicity to humans and the environment, have been used as improved antimicrobial agents for cultural heritage conservation (Marco et al. 2020). There has been considerable attention to using essential oils (EOs) as natural antimicrobial agents for the conservation of cultural heritage. The EOs and their components have been shown to have a broad-range of various properties including antibacterial (Lee et al. 2018; Okla et al. 2019; Behiry et al. 2020; Salem et al. 2021a), and antifungal (Veneranda et al. 2018; Hamad et al. 2019; Elgat et al. 2020; Mansour et al. 2020; Abd-Elkader et al. 2021; Ali et al. 2021; Mansour et al. 2021) properties.

EOs have shown potential antimicrobial activity against the isolated and identified microorganisms from archaeological objects (Mansour et al. 2020). Pimpinella anisum, Origanum vulgare, and Allium sativum EOs showed the best antifungal efficiency against four fungal strains, i.e., Aspergillus clavatus, A. niger, Penicillium sp., and Fusarium sp., which were isolated from the Argentine and Cuban Documentary Heritage Museum; whereas, Origanum vulgare EO suppressed the mycelia growth and sporulation of Aspergillus, Penicillium, and Fusarium sp. (Borrego et al. 2012). In addition, a high antifungal activity was found for five EOs when tested on the Royal Tomb Paint in Tanis, Egypt (Sakr et al. 2012). Veneranda et al. (2018) investigated the antifungal efficacy of EO constituents, i.e., thymol, eugenol, and cinnamaldehyde, on A. niger isolated from a Roman mural painting in Italy, to determine whether these constituents could be used for 
middle and long-term protection applications. Recovery oil ( $\alpha$-bisabolol oxide $\mathrm{A}$, $\mathrm{d}$ limonene, and $\alpha$-bisabolol oxide B), and EO ( $Z$ - $\beta$-farnesene, D-limonene, and $\alpha$-bisabolol oxide A) obtained from fresh Matricaria chamomilla flowers showed potential antifungal activity against some molds isolated from archaeological objects, e.g., Aspergillus niger (from archaeological manuscripts), A. flavus (from a museum gypsum board antique), $A$. terreus (museum archaeological tissue), and F. culmorum (museum organic materials) (ElHefny et al. 2019).

The purpose of this research was to determine the efficacy of the lowest toxicity, environmentally-friendly, and naturally biocides in terms of the conservation of archaeological objects at a minimum effective dose. The isolation and molecular identification of deteriorating fungal and bacterial species from an archaeological object (Ptahshepses stone statue) from the Saqqara excavation, Giza, Egypt were recorded. An evaluation of the effect of six EOs (black cumin, clove, geranium, lavender, lemongrass, and thyme) on microbial growth was carried out. In addition, the EO treatments should not be hazardous to conservators or cause damage to the surfaces being treated.

\section{EXPERIMENTAL}

\section{Investigation and Analysis of the Deteriorated Priest of Ptah Stone Statue}

The statue was badly preserved in the stores of Saqqara, Giza Governorate, Egypt. The statue dates back to the old kingdom of the sixth dynasty, and is of a man seated on a chair, with a bas-relief in lines showing the name of the statue owner, read from left to right crosswise on the seat. The name is the priest of Ptah (Imbi). He is the holder of the royal sacraments, responsible for the establishment of justice for the god Maat. The statue suffered from many deterioration aspects, as follows: the face was broken from the whole statue; and it had been subjected to weathering effects from chemical, physical, and microbial actions. In addition, the Priest of Ptah statue suffered a loss in the painting layer with brown-black spots on its surface, which was accompanied by serious damage (Fig. 1).

\section{$X$-Ray diffraction analysis $(X R D)$}

The analysis and investigation studies were performed on the stone statue to identify the components of the statue, i.e., the type of the stone and the deterioration products. At $40 \mathrm{kV}$ and $30 \mathrm{~mA}$, a Philips PW 3710/31 diffractometer with a -X target tube and Ni filter was used. The APD diffraction software from Philips was used to connect the $\mathrm{Cu}$ instrument to a computer system and the ASTM (American Society for Testing and Materials) card database for mineral identification.

\section{Source of isolation}

The Ptahshepses statue was found at the Saqqara excavation, Giza, Egypt. It was found in a bad state with many deterioration aspects. It had been subjected to weathering effects from chemical, physical, and microbial actions. The statue suffered a loss in the painting layer with brown-black spots on its surface accompanied by serious damage. The microbial species recorded in this research were isolated from the archaeological lime stone statue dated back to the old kingdom of the sixth dynasty. Multi-swabs were collected over several areas of the Ptahshepses stone statue and stored in its sterile packaging to identify the affecting fungal species (Fig. 1). 


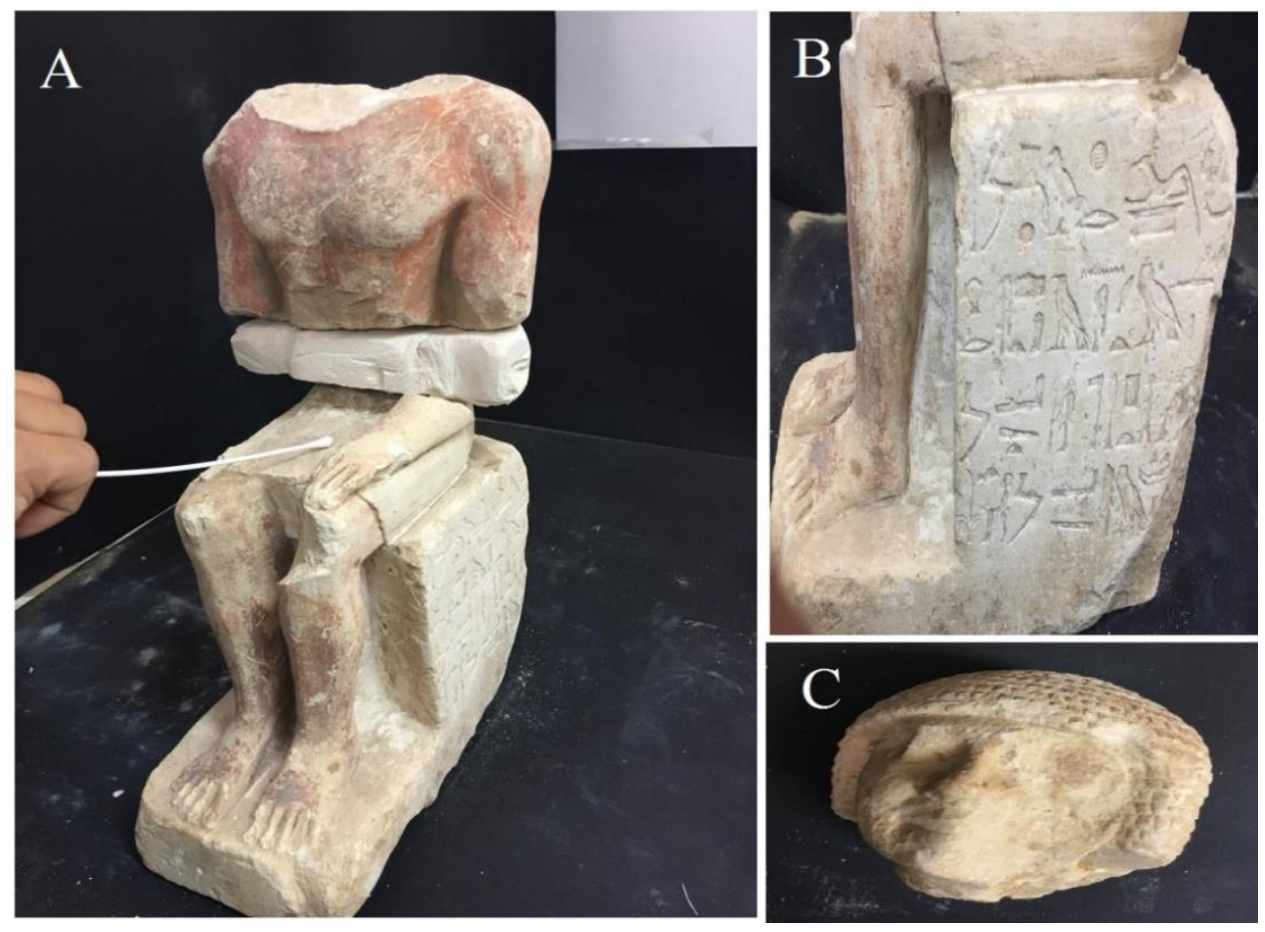

Fig. 1. The tested deteriorated Ptahshepses stone statue found at the Saqqara excavation, Giza, Egypt: (A) the whole stone statue without the face; (B) the loss in pigment layer; and (C) the broken face of the Ptahshepses stone statue

Isolation and identification of the deteriorating microbial species

The samples were obtained from the tested archaeological Ptahshepses stone statue discovered at the Saqqara excavation in Egypt. Sterile swabs were used on the damaged surface of the deteriorated archeological items. For fungi, the inoculated swabs were streaked across Czapeck's Dox agar dishes. These plates were incubated for $7 \mathrm{~d}$ at a temperature of $27^{\circ} \mathrm{C}$, while nutrient agar plates were incubated for $48 \mathrm{~h}$ at a temperature of $37{ }^{\circ} \mathrm{C}$ for the bacterial species (Corte et al. 2003). The isolated fungi were microscopically identified (Gilman 1957; Samson et al. 1981; Kern and Blevins 1997). The isolated bacterial colonies were purified, with every single purified colony identified according to Bergey's Manual of Systematic Bacteriology via biochemical tests (Cowan and Steel 1965; Cowan 2003; Vos et al. 2011). Total count and relative density of the isolated fungal species were measured accorded to Johnson et al. (1992) and Escudero and Mendoza (2005).

\section{Molecular identification of the deteriorating fungal species}

The sequences of the internal transcribed spacer (ITS) rDNA region were used to identify the isolated fungus species using molecular techniques. The DNA was extracted using the Quick DNA ${ }^{\mathrm{TM}}$ Fungal Microprep Kit (Sigma). The fungal universal primers ITS1 (50-TCCGTAGGTGAACCTGCGG-30) and ITS4 (50-TCCTCCGCTTATTGATATGC30) were used to amplify the ribosomal DNA (White et al. 1990). Maxima Hot Start PCR Master Mix was used for PCR (polymerase chain reaction) (Thermo K1051). Electrophoresis of the PCR amplified products was performed in low melting agarose gels (1.5 percent) at $7 \mathrm{~V} / \mathrm{cm}^{2}$ for $1.5 \mathrm{~h}$, and $0.5 \mathrm{~g} / \mathrm{mL}$ of ethidium bromide (EtBr) was used to stain the PCR products, which were then observed under a $305 \mathrm{~nm}$ UV-light (Radford 
1991). The PCR product was cleaned up using the Gene JET ${ }^{\mathrm{TM}}$ PCR Purification Kit (Thermo K0701). The GATC Company used an ABI 3730xl DNA sequencer to sequence the PCR product, employing forward and reverse primers with the latest 454 technology. The forward and reverse sequences of the DNA strand were aligned using the BLAST tool from the NCBI Gen Bank databases (National Center for Biotechnology Information).

\section{Molecular identification of the deteriorating bacterial species}

The bacterial species were grown in a nutrient broth for $24 \mathrm{~h}$ at a temperature of 30 ${ }^{\circ} \mathrm{C}$, and then they were used for DNA extraction (Rashid et al. 2016). The DNA extraction was performed using a GeneJET ${ }^{\mathrm{TM}}$ Genomic DNA purification Kit (Thermo K0721) (Sigma) according to protocol outlined by the manufacturers (Riemann et al. 2000). A Maxima Hot Start PCR Master Mix (Thermo K1051) was used to carry out the PCR (Sigma). The PCR amplification was carried out using PCR with $50 \mu \mathrm{L}$ of sample containing $25 \mu \mathrm{L}$ of the Maxima Hot Start PCR Master Mix (2X), $5 \mu \mathrm{L}$ of the template DNA, $18 \mu \mathrm{L}$ of water (nuclease free), $1 \mu \mathrm{L}(20 \mu \mathrm{M})$ of $27 \mathrm{~F}$ forward primer, and $1 \mu \mathrm{L}$ (20 $\mu \mathrm{M})$ of $1492 \mathrm{R}$ primer. The $27 \mathrm{~F}$ primer sequence was (5'-AGAGTTTGATCMTGGCTCAG-3'), and the 1492R primer sequence was (5'-TACGGYTACCTTGTTACGACTT$3^{\prime}$ ) (Lane). Amplification of the PCR products was performed using the following thermal cycling conditions: an initial denaturing step of $10 \mathrm{~min}$ at $95{ }^{\circ} \mathrm{C}$ ( 1 cycle $), 35$ cycles of denaturation at $95^{\circ} \mathrm{C}$ for $30 \mathrm{~s}$, annealing at $65^{\circ} \mathrm{C}$ for $1 \mathrm{~min}$, and elongation at $72{ }^{\circ} \mathrm{C}$ for 90 $\mathrm{s}$, with a final extension cycle at $72{ }^{\circ} \mathrm{C}$ for $10 \mathrm{~min}$.

A Gene JET ${ }^{\mathrm{TM}}$ PCR Purification Kit was used to clean up the PCR product (Thermo K0701). The GATC Company used an ABI 3730xl DNA sequencer to sequence the PCR product, employing forward and reverse primers with the latest 454 technology. The BLAST program (National Center for Biotechnology Information), available in the NCBI Gen Bank databases, was used to align the forward and reverse sequences of the DNA strand. The amplified 16S rDNA segment of the isolate was sequenced and compared to a number of non-redundant NCBI nucleotide sequence databases. The examination of hits from the mega-blast (very similar sequences) output was used to identify isolates. Sequences of $16 \mathrm{~S}$ rDNA hits were used in a phylogenetic analysis of isolate $16 \mathrm{~S}$ rDNA sequences in order to identify the evolutionary link between isolates and hits. The isolation 16S rRNA gene segments were sequenced and identified using standard techniques (Bhore et al. 2010).

\section{Tested essential oils}

Six essential oils (EOs) including black cumin (Nigella sativa seeds) clove (Syzygium aromaticum flower buds), geranium (Pelargonium graveolens leaves), lavender (Lavandula angustifolia leaves), lemongrass (Cymbopogon citratus leaves), and thyme (Thymus vulgaris leaves) were used. These EOs were provided by the Natural Oils Department, at the National Research Center in Dokki, Egypt. The EOs were extracted using a Clevenger-type device and hydrodistilled for $3 \mathrm{~h}$ (Badawy et al. 2017; Moustafa et al. 2021). Until needed, the extracted oils were kept in the dark at a temperature of $4{ }^{\circ} \mathrm{C}$.

\section{Antifungal activity of the tested essential oils}

The antifungal activities of the six tested EOs were evaluated via the agar dilution method (Ishii 2017). The EOs were diluted in melted Czapeck's Dox agar at different concentrations $(0.1,0.25,0.5,1$, and $2 \mu \mathrm{L} / \mathrm{mL})$ with vigorous shaking, then poured in Petri plates $(9 \mathrm{~cm}$ diameter) and allowed to solidify. Each plate was inoculated at the center with 
a fungal disc $(6 \mathrm{~mm})$ from a 7-day-old culture. Itraconazole was used as a positive control, and sterilized distilled water was used as a negative control. All dishes were tested in triplicate and incubated at a temperature of $27^{\circ} \mathrm{C}$ for $7 \mathrm{~d}$. The inhibitory percentage of the tested EOs on the radial growth of the fungal mycelium was calculated according to Eq. 1,

$$
\text { Percent of inhibition }=d_{C}-d_{T} \times \frac{100}{d_{C}}
$$

where $d_{C}$ is the average diameter $(\mathrm{cm})$ of the fungal colony in the control and $d_{\mathrm{T}}$ is the average diameter $(\mathrm{cm})$ of the fungal colony in a treatment group (Salem et al. 2021b).

\section{Antibacterial activity of the six tested essential oils}

The antibacterial activities of the six tested EOs were determined via the disc diffusion method, where the isolated bacterial species were swabbed on the surface of the nutrient agar in Petri dishes, then discs of Whatman filter paper $(6 \mathrm{~mm})$ were saturated with EOs at different concentrations $(0.1,0.25,0.5,1$, and $2 \mu \mathrm{L} / \mathrm{mL})$ and placed on the surface of the previously inoculated media. Chloramphenicol was used as the control. For $48 \mathrm{~h}$, all the plates (in triplicate) were incubated at a temperature of $37{ }^{\circ} \mathrm{C}$. The diameter of the inhibitory zone was measured in mm (Mosa et al. 2021). The percent inhibition (PI) was calculated for all EOs according to Eq. 2,

$$
P I=\frac{Z_{\text {oil }}}{Z_{S}} \times 100
$$

where $Z_{\mathrm{oil}}$ is the mean zone of inhibition of each $\mathrm{EO}$ and $Z_{\mathrm{s}}$ is the zone of inhibition obtained for the standard antibiotic (Chloramphenicol) (Ali-Shtayeh et al. 2018).

Determination of the minimum inhibitory concentration (MIC) of the six tested essential oils on the isolated deteriorating fungal species

The agar dilution method was used to determine the minimum inhibitory concentration (MIC) of the six evaluated EOs. The tested EOs were diluted in melted Czapek's dox agar at different concentrations $(0.1,0.25,0.5,1$, and $2 \mu \mathrm{L} / \mathrm{mL})$ with vigorous shaking, and then the media was poured into Petri dishes and let to solidify. Each plate was inoculated with a fungal disc $(6 \mathrm{~mm})$ in the center. The plates (in triplicate) were incubated at a temperature of $27^{\circ} \mathrm{C}$ for $7 \mathrm{~d}$. The MIC of the six tested Eos were expressed as the lowest concentration of EOs ( $\mu \mathrm{L}$ of the $\mathrm{EO} / \mathrm{mL}$ of culture medium) at which no visible growth occurred compared with the control (Adam et al. 1998).

Determination of the minimum inhibitory concentration (MIC) of the six tested essential oils on the isolated deteriorating bacterial species

The MIC of the six tested EOs was demonstrated by diluting the EOs in nutrient agar at a temperature of $45^{\circ} \mathrm{C}$ with different concentrations $((0.1,0.25,0.5,1$, and 2 $\mu \mathrm{L} / \mathrm{mL}$ ) with vigorous shaking. Then, the media was poured into Petri plates and allowed to solidify. Then the isolated bacteria was swabbed on the surface of the nutrient agar. The positive control consisted of the inoculated nutrient agar without EO. Non-inoculated plates containing essential oils were used as a negative control. Three plates (in triplicate) were incubated at a temperature of $37{ }^{\circ} \mathrm{C}$ for $48 \mathrm{~h}$. The MIC of the tested EOs was expressed as the lowest concentration of EOs ( $\mu \mathrm{L}$ of the $\mathrm{EO} / \mathrm{mL}$ of culture medium) at which no visible growth occurred compared with the control (Oussalah et al. 2007). 


\section{Statistical Analysis}

The antibacterial and antifungal activities of the EOs were calculated using the mean \pm and standard deviation of the triplicate samples for each sample. The one-way ANOVA (analysis of variance) was done using Statistical Analysis Software (SAS, Release 8.02, Cary, NC, USA) system, which was followed by a Least Significant Difference (LSD) with a significant level of a $p$-value less than 0.05 , according to Colao $e t$ al. (2005).

\section{RESULTS AND DISCUSSION}

\section{X-Ray Diffraction Analysis (XRD)}

The chemical composition of the statue, according to the results of the analysis, was essentially calcite $\left(\mathrm{CaCO}_{3}\right)$, the major component of limestone. However, traces of gypsum $\left(\mathrm{CaSO}_{4} \cdot 2 \mathrm{H}_{2} \mathrm{O}\right)$, quartz $\left(\mathrm{SiO}_{2}\right)$, halite $(\mathrm{NaCl})$, and hematite $\left(\mathrm{Fe}_{2} \mathrm{O}_{3}\right)$ were also detected (Fig. 2). According to Geweely et al. (2019), the primary components of archaeological wall painting stone is calcite, magnesium, and syn $(\mathrm{Mg} 0.06 \mathrm{Ca} 0.94)\left(\mathrm{CO}_{3}\right)$, which has a concentration of approximately $98 \%$, while the high $\mathrm{Ca}, \mathrm{S}$, and $\mathrm{O}$ concentrations can be attributed to the ground painting layer matrix, which contains $\mathrm{Si}, \mathrm{C}$, and small amounts of $\mathrm{Al}, \mathrm{Mg}$, which may be interpreted as gypsum. Furthermore, the results supported the assertion by Clark and Zoitos (1992) that fungus grows best on quartz. Red ochre was documented to have been utilized in ancient Egypt (Casadio and Toniolo 2001).

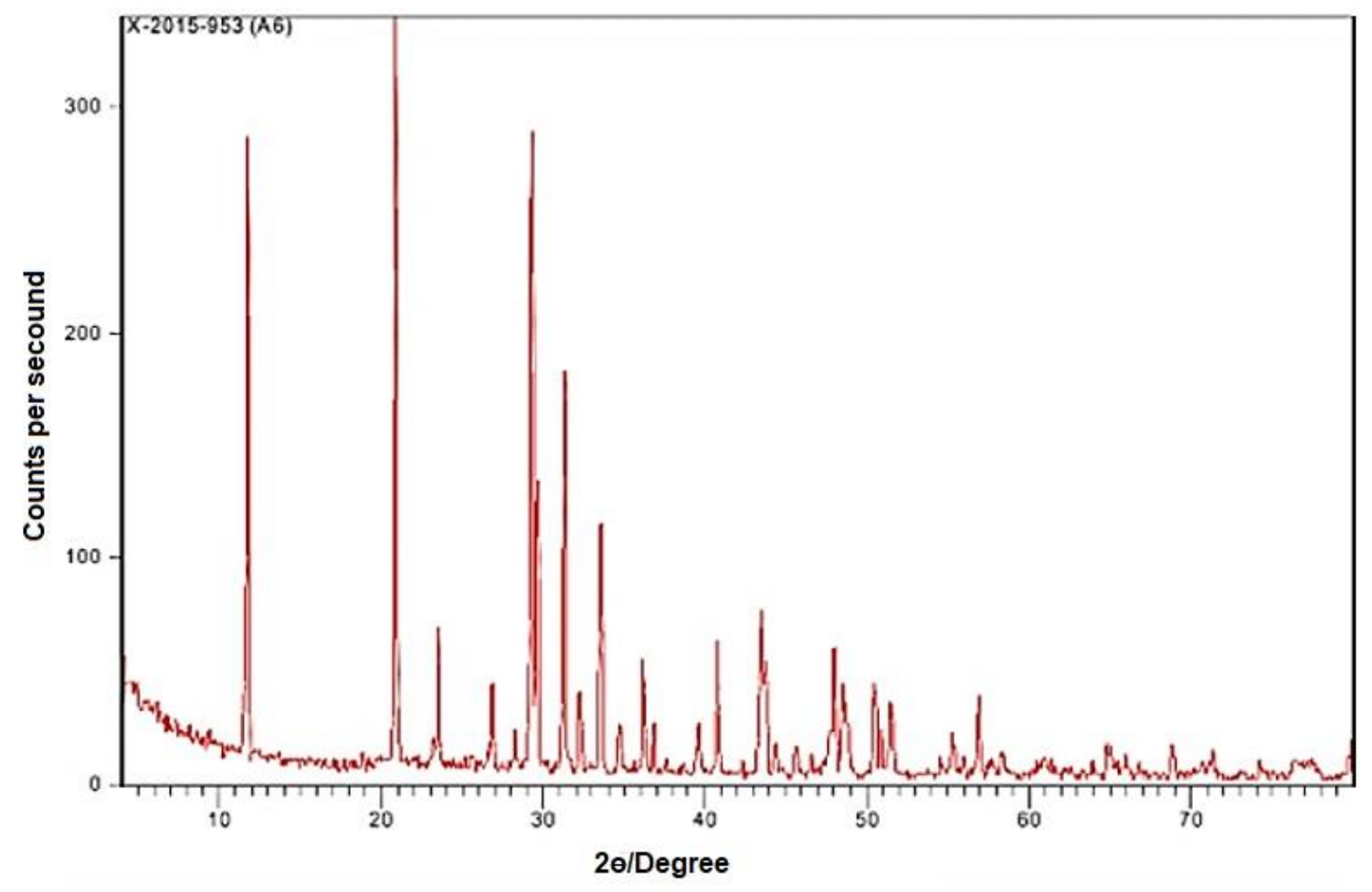

Fig. 2. The XRD pattern of the stone statue confirmed the presence of gypsum, calcite, hematite, halite and quartz 
Isolation of the fungal and bacterial species

Six deteriorating fungal species (Alternaria alternate, Aspergillus flavus, Aspergillus niger, Cladosporium halotolerans, Penicillium crustosum, and Trichoderma viride), which accounted for 80 colonies, and three bacterial species (Pseudomonas protegens, $P$. putida, and Serratia odorifera) were isolated from the tested archaeological Ptahshepses stone statue found at the Saqqara excavation, Giza, Egypt (as shown in Table 1). The presence of fungal species on the tested stone statue for prolonged periods of time may be due to their potency at forming spores, which are more resistant to drought, as stated by Zhang et al. (2019). In addition, they stated that the fungal species are capable of producing different organic acids that deteriorate the stone surface, and also promote the development of other microorganisms. Furthermore, the fungal laccase systems are responsible for the resources competition and spreading on the stone surface.

Table 1. Total Count and Relative Density of the Fungal Species Isolated from the Tested Archaeological Ptahshepses Stone Statue Found at the Saqqara Excavation, Giza, Egypt.

\begin{tabular}{|c|c|c|}
\hline Fungal Species & Count of Species & Relative Density (\%) \\
\hline Alternaria alternata & 10 & 12.5 \\
\hline Aspergillus flavus & 25 & 31.25 \\
\hline Aspergillus niger & 19 & 23.75 \\
\hline Cladosporium halotolerans & 3 & 3.75 \\
\hline Penicillium crustosum & 16 & 20 \\
\hline Trichoderma viride & 7 & 8.75 \\
\hline Total count & 80 & 100 \\
\hline Number of species & 6 & \\
\hline
\end{tabular}

Aspergillus flavus and A. niger were the most dominant tested isolated fungal species with a relative density of $31.2 \%$ and $23.8 \%$, respectively. The obtained results were in accordance with Geweely et al. (2019), who isolated Aspergillus flavus and A. niger from archaeological funeral masks in Saqqara, Egypt. The fungi had caused various deterioration aspects, i.e., disintegration, discoloration, cracking, and stains. Mellon et al. (2007) stated that $A$. flavus has the ability to produce a broad range of hydrolytic enzymes that are substantial in terms of the nutrition and penetration of different organic substrates. Aspergillus niger is considered as a biodeterioration factor of culture heritage, as it can be adapted to various environmental conditions by different metabolic mechanisms (Zhang et al. 2017). The degradation action of $A$. niger is performed by the production of pectinases, hemicellulase, xylanases, and arabinases (Parenicová et al. 2000). Aspergillus niger, Penicillium sp., and Cladosporium sp. were the most frequent microorganisms in the deteriorated marble and stucco of the historic mosques in Cairo, Egypt (Afifi 2012; Aldosari et al. 2019). In addition, at the Saqqara Excavation in Egypt, researchers discovered a new comparative efficiency of ozone and gamma sterilization on the fungal deterioration of archeological painted coffins (Geweely et al. 2014).

The halophile microorganisms, i.e., Penicillium sp. and Aspergillus sp., have developed various mechanisms of adaptation depending on the accumulation and biosynthesis of organic osmotic solutes, i.e., sugar, sugar alcohols, amino acids, and amino acid by-products (Ortiz et al. 2014). The surfaces of the stone artifacts can be modified by hyphal penetration of fungi through the porous stone template and by the realization of the 
pigments and organic acids (Sterflinger 2010; Kavita et al. 2011). Through oxidation, reduction, and transformation of metal ions, the acidification of the archaeological artefact enhances fungal growth and increases chemical biodeterioration (Gorbushina et al. 2004). Penicillium sp., Alternaria sp., Allophoma sp., and Fusarium sp. were isolated from the upper part of the Pompeian mural paintings conserved in the basement of the Ariadne House in Pompeii, Italy (Veneranda et al. 2017). Pseudomonas sp., Bacillus sp., Alternaria alternate, Penicillium sp., Curvularia sp., and Fusarium sp. caused deterioration of the archaeological walls of a pre-Hispanic ancient city in Mexico (Carrillo-González et al. 2016).

The most biodeteriorative microorganisms of cultural heritage were found to be fungal species A. versicolor, Alternaria alternata, Aureobasidium spp., Chaetomium spp., Penicillium aurantiogriseum, P. chrysogenum, P. expansum, Stachybotrys chartarum, Trichoderma viride, and Ulocladium spp., as well as bacterial species Micrococcus, Aerobacter, Bacillus, Clostridium, Streptomyces, Staphylococcus, and Actinomyces (Grabek-Lejko et al. 2017). In addition, the microorganisms responsible for the biodeterioration of the archeological objects in three Jordanian Museums (Yarmouk) are A. niger, A. fumigates, A. nidulans, Penicillium chrysogenum, P. digitatum, P. italicum, Pythium sp., yeast, Bacillus subtilis, B. cereus, Micrococcus spp., Corynebacterium aquaticum, C. pseudodiphtheriticum, $C$. pyogenes, Escherichia coli, Listeria monocytogenes, Pseudomonas pseudoaclingenes, Salmonella sp., and Staphylococcus aureus (Elserogy et al. 2016).

Alternaria, Fusarium, and Penicillium species were observed colonizing rocks (Sterflinger 2010). In addition, Aspergillus, Beauveria, Curvularia, Cochliobolus, Chrysosporium, Conidiobolus, Fusarium, Penicillium, Sepedonium, Scopulariopsis, Trichothecium, Torula, and Ulocladium genera were isolated from archaeological sites in India (Pandey et al. 2011). Epicoccum nigrum, Alternaria alternate, A. atra, Dothiorella iberica, and Cladosporium cladosporioides were isolated from archaeological stones in Fiesole (Italy) (Pinna et al. 2018).

The data from this study demonstrated that the three isolated bacterial species (Pseudomonas protegens, P. putida, and Serratia odorifera) were associated with the deterioration of the tested stone statue by different mechanisms (Zhang et al. 2019). These authors estimated that the bacteria produce color and pigments, as well as organic and inorganic acids, which are responsible for the destruction of the stone surface. Several bacterial species are able to grow in stone. For instance, Micrococcus was isolated from different types of stones, which produces exopolysaccharide substances (Urzì et al. 1991). Methanol, fructose methylamine, and trimethylamine are examples of products that haloalkalophilic and methylotrophic bacteria can use as energy and carbon sources (Doronina et al. 1997, 2003). The level of decomposition will differ depending on the amount of organic material available (Caple 2001).

\section{Molecular identification of the isolated fungal species}

The six isolated fungal species, i.e., Alternaria alternate, Aspergillus flavus, A. niger, Cladosporium halotolerans, Penicillium crustosum, and Trichoderma viride, from the tested archaeological Ptahshepses stone statue found at the Saqqara excavation were identified at the molecular level via the DNA sequencing of the PCR products. The six fungal species had the following accession numbers: Alternaria alternate (MN512215), Aspergillus flavus (MN517993), A. niger (MN513383), C. halotolerans (MN512648), Penicillium crustosum (MN512539), and Trichoderma viride (MN513046) (Table 2). The 
phylogenetic trees showed their link with other related fungal species (Fig. S1 through Fig. S5).

Table 2. The Fungal and Bacterial Species Isolated from the Tested Archaeological Ptahshepses Stone Statue Found at the Saqqara Excavation and Their Accession Numbers

\begin{tabular}{|c|c|c|}
\hline \multirow{2}{*}{ Class } & Species & GenBank Accession Number \\
\hline \multirow{4}{*}{ Fungal species } & Alternaria alternata & MN512215 \\
\cline { 2 - 3 } & Aspergillus flavus & MN517993 \\
\cline { 2 - 3 } & A. niger & MN513383 \\
\cline { 2 - 3 } & Cladosporium halotolerans & MN512648 \\
\cline { 2 - 3 } & Penicillium crustosum & MN512539 \\
\cline { 2 - 3 } Bacterial species & Trichoderma viride & MN513046 \\
\cline { 2 - 3 } & Pseudomonas protegens & MN514045 \\
\cline { 2 - 3 } & P. putida & MN514087 \\
\cline { 2 - 3 } & \multicolumn{2}{|c|}{ Serratia odorifera } \\
\hline
\end{tabular}

Molecular identification of the isolated bacterial species

The three isolated bacterial species, i.e., Pseudomonas protegens, P. putida, and Serratia odorifera, from the tested archaeological Ptahshepses stone statue found at the Saqqara excavation were identified at the molecular level via the 16S rRNA sequencing of the PCR products. The $16 \mathrm{~S}$ rRNA gene of the three isolated bacterial species was amplified via PCR. The three bacterial species had the following accession numbers: P. protegens (MN514045), P. putida (MN514087), and Serratia odorifera (MN514046) (Table 2). The phylogenetic trees showed their link with other related bacterial species (Fig. S6 through Fig. S8).

The impact of the six essential oils on the radial growth of six isolated fungal species

The six EOs exhibited antifungal efficacy against six fungal species that were isolated from the Ptahshepses stone statue, found at the Saqqara excavation, Egypt (Table 3). Thymus vulgaris, Syzygium aromaticum and Cymbopogon citratus EOs were the most active. Based on the authors' previous works, the main compounds identified in the EO of lemongrass were $\alpha$-citral (35.91\%), $\beta$-citral (35\%) 5-octyldihydro-2(3H)-furanone (9.08\%), and nerylacetal (7.84\%) (Moustafa et al. 2021). Eugenol was the abundant compound found in S. aromaticum EO (99.16\%) (Salem et al. 2020). Thymol, p-cymene, and carvacrol were the most abundant compounds in T. vulgaris EO (Geweely et al. 2019). Among all the tested EOs, the thyme EO at a low concentration $(0.5 \mu \mathrm{L} / \mathrm{mL})$ exhibited the most efficient antifungal activity against all six isolated deteriorating fungal species, with the percent of inhibition ranging from $94.3 \%$ to $100 \%$. Rota et al. (2008), reported that thymol and $p$-cymene were the major components of $T$. vulgaris EO, which had strong antimicrobial efficiency. The $p$-cymene compound is able to reduce ATP synthesis by decoupling the respiratory chain in microbial cells (Custódio et al. 2011). The breakdown of microbial cell membranes and the precipitation of cellular proteins is linked to the antibacterial activity of the phenolic chemicals in the thyme EO (ElBaghdady et al. 2019). In this relation, Noshyutta et al. (2016) stated that the fungicidal activity of the thyme EO can be used as an alternative preservative for an ancient Egyptian Coptic cellulosic manuscript. 
Table 3. Antifungal Activity of the Six Essential Oils on the Six Isolated Deteriorating Fungal Species from the Archaeological Tested Ptahshepses Stone Statue via the Agar Dilution Method $\left.{ }^{*}\right)$

\begin{tabular}{|c|c|c|c|c|c|c|c|}
\hline \multirow[b]{2}{*}{ Essential Oils } & \multirow[b]{2}{*}{ Concentration } & \multicolumn{6}{|c|}{ Inhibitory Percentage of Fungal Mycelium Radial Growth (\%) } \\
\hline & & $\begin{array}{l}\text { Alternaria } \\
\text { alternata }\end{array}$ & $\begin{array}{l}\text { Aspergillus } \\
\text { flavus }\end{array}$ & $\begin{array}{c}\text { Aspergillus } \\
\text { niger }\end{array}$ & $\begin{array}{c}\text { Cladosporium } \\
\text { halotolerans }\end{array}$ & $\begin{array}{l}\text { Penicillium } \\
\text { crustosum }\end{array}$ & $\begin{array}{c}\text { Trichoderma } \\
\text { viride }\end{array}$ \\
\hline Control $^{\#}$ & & $66.5^{\mathrm{k}} \pm 0.2$ & $69.2^{m} \pm 0.1$ & $55.4^{j} \pm 0.2$ & $27.8^{\mathrm{c}} \pm 0.2$ & $44.1^{9} \pm 0.1$ & $76^{\prime} \pm 0.1$ \\
\hline \multirow{5}{*}{ Black cumin } & 0.1 & $11.4^{\mathrm{b}} \pm 0.2$ & $7.8^{\mathrm{b}} \pm 0.1$ & $3.4^{\mathrm{a}} \pm 0.0$ & $13.7^{\mathrm{b}} \pm 0.1$ & $16.1^{\mathrm{b}} \pm 0.1$ & $22.8^{\mathrm{b}} \pm 0.0$ \\
\hline & 0.2 & $23.3^{\mathrm{c}} \pm 0.2$ & $36.4^{\dagger} \pm 0.3$ & $21.4^{\mathrm{c}} \pm 0.1$ & $44.2^{f} \pm 0.1$ & $32.1^{d} \pm 0.1$ & $53.2^{\mathrm{g}} \pm 0.1$ \\
\hline & 0.5 & $41.1^{\dagger} \pm 0.2$ & $63^{k} \pm 0.1$ & $50^{\mathrm{h}} \pm 0.0$ & $72.2^{\mathrm{k}} \pm 0.1$ & $64.2^{\mathrm{j}} \pm 0.2$ & $75.8^{1} \pm 0.2$ \\
\hline & 1 & $58.5^{\mathrm{j}} \pm 0.1$ & $76.7^{\circ} \pm 0.1$ & $60.3^{k} \pm 0.1$ & $93.3^{\circ} \pm 0.1$ & $84.1^{\prime} \pm 0.1$ & $89.7^{\circ} \pm 0.2$ \\
\hline & 2 & $84.3^{p} \pm 0.1$ & $87.5^{s} \pm 0.1$ & $76.1^{r} \pm 0.1$ & $100^{r} \pm 0$ & $100^{\circ} \pm 0$ & $100^{s} \pm 0$ \\
\hline \multirow{5}{*}{ Clove } & 0.1 & $50.6^{i} \pm 0.3$ & $42^{g} \pm 2.0$ & $42^{\dagger} \pm 0.1$ & $32.5^{d} \pm 0.1$ & $36.2^{\mathrm{e}} \pm 0.1$ & $43.1^{d} \pm 0.1$ \\
\hline & 0.2 & $68.5^{\prime} \pm 0.2$ & $67.4^{\prime} \pm 0.2$ & $65.9^{m} \pm 0.1$ & $57.9^{h} \pm 0.1$ & $84.1^{\prime} \pm 0.1$ & $81.2^{m} \pm 0.1$ \\
\hline & 0.5 & $100^{t} \pm 0$ & $86.2^{r} \pm 0.1$ & $78.3^{s} \pm 0.1$ & $81.3^{m} \pm 0.1$ & $99.7^{\circ} \pm 0$ & $97.3^{q} \pm 0.1$ \\
\hline & 1 & $100^{t} \pm 0$ & $100^{\mathrm{u}} \pm 0$ & $99.3^{w} \pm 0$ & $100^{r} \pm 0$ & $100^{\circ} \pm 0$ & $100^{s} \pm 0$ \\
\hline & 2 & $100^{t} \pm 0$ & $100^{u} \pm 0$ & $100^{w} \pm 0$ & $100^{r} \pm 0$ & $100^{\circ} \pm 0$ & $100^{s} \pm 0$ \\
\hline \multirow{5}{*}{ Geranium } & 0.1 & $43.2^{g} \pm 0.1$ & $29.2^{d} \pm 0.1$ & $38.4^{d} \pm 0.1$ & $27.6^{c} \pm 0.2$ & $28.1^{c} \pm 0.1$ & $35.2^{c} \pm 0.1$ \\
\hline & 0.2 & $66.4^{\mathrm{k}} \pm 0.2$ & $43.2^{h} \pm 0.1$ & $62.6^{\prime} \pm 0.1$ & $51.2^{\mathrm{g}} \pm 0.1$ & $52.2^{\mathrm{h}} \pm 0.2$ & $54.3^{h} \pm 0.1$ \\
\hline & 0.5 & $86.7^{q} \pm 0.2$ & $84.6^{q} \pm 0.3$ & $71.6^{p} \pm 0.1$ & $72.2^{k} \pm 0.2$ & $76.2^{k} \pm 0.1$ & $92.3^{p} \pm 0.2$ \\
\hline & 1 & $100^{t} \pm 0$ & $99.67^{\mathrm{u}} \pm 0$ & $99.6^{w} \pm 0$ & $99.3^{q} \pm 0$ & $100^{\circ} \pm 0$ & $100^{s} \pm 0$ \\
\hline & 2 & $100^{t} \pm 0$ & $100^{\mathrm{u}} \pm 0$ & $100^{w} \pm 0$ & $100^{r} \pm 0$ & $100^{\circ} \pm 0$ & $100^{s} \pm 0$ \\
\hline \multirow{5}{*}{ Lavender } & 0.1 & $7.9^{a} \pm 0.1$ & $1.5^{\mathrm{a}} \pm 0.1$ & $19.3^{b} \pm 0.1$ & $9.1^{a} \pm 0.1$ & $8^{a} \pm 0.0$ & $10.1^{\mathrm{a}} \pm 0.1$ \\
\hline & 0.2 & $25.2^{d} \pm 0.2$ & $18.3^{\mathrm{c}} \pm 0.1$ & $39.8^{\mathrm{e}} \pm 0.1$ & $27.9^{c} \pm 0.1$ & $32^{\mathrm{d}} \pm 0.1$ & $49.2^{\mathrm{e}} \pm 0.1$ \\
\hline & 0.5 & $39.3^{e} \pm 0.2$ & $52.2^{i} \pm 0.1$ & $53.2^{i} \pm 0.1$ & $44.2^{f} \pm 0.1$ & $60^{i} \pm 0.0$ & $68.2^{k} \pm 0.1$ \\
\hline & 1 & $49.2^{h} \pm 0.1$ & $72.1^{n} \pm 0.1$ & $67^{n} \pm 0.1$ & $58.2^{h} \pm 0.1$ & $76.3^{k} \pm 0.1$ & $88.3^{n} \pm 0.2$ \\
\hline & 2 & $72.3^{m} \pm 0.1$ & $86.2^{r} \pm 0.1$ & $79.6^{t} \pm 0.2$ & $74.2^{\prime} \pm 0.1$ & $100^{\circ} \pm 0$ & $100^{s} \pm 0$ \\
\hline \multirow{3}{*}{ Lemongrass } & 0.1 & $58.8^{\mathrm{j}} \pm 0.1$ & $33.7^{e} \pm 0.1$ & $53.4^{i} \pm 0.1$ & $46.3 \pm 0.2$ & $40.2^{f} \pm 0.2$ & $50.6^{\dagger} \pm 0.1$ \\
\hline & 0.2 & $74.3^{n} \pm 0.1$ & $55.2^{\mathrm{j}} \pm 0.1$ & $68.2^{\circ} \pm 0.1$ & $65.2^{i} \pm 0.1$ & $60.2^{i} \pm 0.1$ & $67^{j} \pm 0.0$ \\
\hline & 0.5 & $88.3^{r} \pm 0.2$ & $90.8^{t} \pm 0.1$ & $87.4^{u} \pm 0.1$ & $100^{r} \pm 0$ & $88.2^{m} \pm 0.1$ & $98.8^{r} \pm 0.1$ \\
\hline
\end{tabular}




\section{bioresources.com}

\begin{tabular}{|c|c|c|c|c|c|c|c|}
\hline & 1 & $100^{t} \pm 0$ & $100^{u} \pm 0$ & $99.3^{w} \pm 0$ & $100^{r} \pm 0$ & $100^{\circ} \pm 0$ & $100^{s} \pm 0$ \\
\hline & 2 & $100^{t} \pm 0$ & $100^{u} \pm 0$ & $100^{w} \pm 0$ & $100^{r} \pm 0$ & $100^{\circ} \pm 0$ & $100^{s} \pm 0$ \\
\hline \multirow{5}{*}{ Thyme } & 0.1 & $58.4^{j} \pm 0.2$ & $55.2^{j} \pm 0.1$ & $43.3^{g} \pm 0.2$ & $39.3^{\mathrm{e}} \pm 0.2$ & $44.1^{g} \pm 0.1$ & $63.1^{i} \pm 0.1$ \\
\hline & 0.2 & $78.2^{\circ} \pm 0.1$ & $81.3^{p} \pm 0.1$ & $73.8^{q} \pm 0.1$ & $67.2^{\mathrm{j}} \pm 0.1$ & $96.4^{n} \pm 0.2$ & $81.2^{m} \pm 0.1$ \\
\hline & 0.5 & $94.3^{s} \pm 0.2$ & $100^{x} \pm 0$ & $95.5^{\vee} \pm 0.1$ & $95.3^{p} \pm 0.1$ & $100^{\circ} \pm 0$ & $100^{s} \pm 0$ \\
\hline & 1 & $100^{t} \pm 0$ & $100^{\mathrm{u}} \pm 0$ & $99.6^{w} \pm 0$ & $100^{r} \pm 0$ & $100^{\circ} \pm 0$ & $100^{s} \pm 0$ \\
\hline & 2 & $100^{t} \pm 0$ & $100^{\mathrm{u}} \pm 0$ & $100^{w} \pm 0$ & $100^{r} \pm 0$ & $100^{\circ} \pm 0$ & $100^{s} \pm 0$ \\
\hline \multicolumn{2}{|c|}{ LSD 0.05} & 5.93 & 6.32 & 5.71 & 7.98 & 6.34 & 5.48 \\
\hline
\end{tabular}

Note: \#: Positive control: Itraconazole

$\left({ }^{*}\right)$ is the percent inhibition of fungal growth; numbers are expressed as the mean \pm standard deviation $(n=3)$ for each sample; and different letters in each column show mean value at a significant level ( $p$-value less than 0.05). Means with the same letter/s within the same column are not significantly different according to LSD at level of probability 0.05 . 
The second highest ranked tested EO in terms of conservation of the tested archaeological object was the lemongrass EO. Lemongrass EO and its major components (citronellal and geraniol) have antimicrobial activity, which induces shrinkage of the cell wall and disruption of the cell membrane resulting in lysis of the microbial cells (Sahal et al. 2020). Citral and the other terpenes in lemongrass break down the integrity of the cellular wall to be disrupted, causing the homeostasis of the microbial cell to be disrupted (Hadjilouka et al. 2017). Therefore, exposure of the genes involved in fatty acid biosynthesis or peptidoglycan biosynthesis may affect the expression of lemongrass EO. In this relation, citral, which was extracted from the lemongrass EO, was tested against the Aspergillus niger collected from a mural painting in the basement of the Ariadne House, Pompeii, Italy (Veneranda et al. 2018). Lemongrass EO has antimicrobial efficiency against fungi, yeasts, and Gram-positive and Gram-negative bacteria (Mendes et al. 2020).

In the present study, the tested clove EO $(1 \mu \mathrm{L} / \mathrm{mL})$ showed significant inhibition against the six isolated fungal species with a percent of inhibition above $99 \%$. The antifungal activity of clove EO may be assigned to the presence of eugenol. It was suggested that eugenol is an important element in the antifungal efficiency of clove EO (Xie et al. 2017). In addition, the findings of this study were consistent with the findings of Veneranda et al. (2018), who assessed the potential exploitation of clove EO as a novel preservative against the biological colonization of archaeological sites. The bioactive compound antifungal feature of the clove EO could be attributed to its lipophilic nature, which facilitated the penetration of the fungal membrane lipid bilayer and led to the disruption of the membrane (Sharma et al. 2018). The hydroxyl eugenol group can bind to proteins and block microbial amino acid decarboxylases in microbial species (Omonijo et al. 2018).

The tested geranium EO caused the complete inhibition of three isolated deteriorating fungal species, i.e., Alternaria alternata, Penicillium crustosum, and Trichoderma viride, at $1 \mu \mathrm{L} / \mathrm{mL}$, while the three rest of the fungal species were inhibited by $2 \mu \mathrm{L} / \mathrm{mL}$ of geranium. Citronellol and geraniol, as the major compounds of geranium EO, as noted by Zore et al. (2011), can damage membrane integrity, impedes germs, and inhibits the microbial cell cycle, which may be due for the antimycotic activity of the test geranium EOs. The tested black cumin EO showed moderate activity against the isolated fungal species at low concentrations, and its activity increased as the EO concentration increased. The antimicrobial efficiency of the tested black cumin EO may be related to the presence of a high level of phenolics in the black cumin EO, which are considered as powerful active compounds with a strong antimicrobial efficiency (Luther et al. 2007). The black cumin EO contained high concentrations of thymoquinone, and its associated compounds, i.e., thymol and dithymoquinone, which have antimicrobial activities (Singh et al. 2005). The components of the black cumin EO are directly related to the inhibition of fungal cell growth, which depends on the used dose (Santos et al. 2018).

The least efficient EO was the lavender EO, which had the lowest efficient antifungal activity against all six isolated deteriorating fungal species at the highest concentration $(2 \mu \mathrm{L} / \mathrm{mL})$ with the percent of inhibition ranging from $72.3 \%$ to $100 \%$. Rakotonirainy and Lavédrine (2005) suggested that the antifungal properties of Lavandula angustifolia EO against fungal species isolated from the library and archive storage regions were due to the presence of linalool and linalool acetate as the major components.

Aspergillus niger was the most resistant species to the six tested essential oils, which may due to several resistance mechanisms, i.e., producing biofilms, permeability of cell walls, over-expression of the target site, modifications to paths, incompatibility with 
the objective, system of drug efflux, and reaction to stress, as recorded by Roilides and Iosifidis (2019). These authors stated that the resistance of fungal species, including Aspergillus spp., against antifungal drugs may be due to primary resistance or secondary mechanisms of resistance after exposure to antifungals and the selection of resistant clones.

The impact of the six tested essential oils on the growth of the isolated bacterial species of the stone statue

The results in Table 4 reveal that the six tested EOs at different concentrations $(0.1$, $0.25,0.5,1$, and $2 \mu \mathrm{L} / \mathrm{mL}$ ) exhibited a variable degree of antibacterial activity against the three isolated deteriorating bacterial species.

Table 4. Antibacterial Activity of the Six Essential Oils on the Three Isolated Deteriorating Bacterial Species from the Archaeological Tested Ptahshepses Stone Statue via the Disc Diffusion Method $\left.{ }^{*}\right)$

\begin{tabular}{|c|c|c|c|c|}
\hline \multirow{2}{*}{ Essential Oils } & \multirow{2}{*}{$\begin{array}{l}\text { Concentration } \\
\qquad(\mu \mathrm{L} / \mathrm{mL})\end{array}$} & \multicolumn{3}{|c|}{ Percent of Inhibition (PI\%) } \\
\hline & & P. protegens & P. putida & S. odorifera \\
\hline Control & & $15.7^{d} \pm 0.3$ & $20^{c} \pm 0.6$ & $29.7^{d} \pm 0.3$ \\
\hline \multirow{5}{*}{ Black cumin } & 0.1 & $0^{\mathrm{a}} \pm 0.0$ & $0^{\mathrm{a}} \pm 0.0$ & $0^{\mathrm{a}} \pm 0.0$ \\
\hline & 0.2 & $12.5^{\mathrm{c}} \pm 0.1$ & $9.7^{b} \pm 0.3$ & $33.1^{\mathrm{e}} \pm 0.1$ \\
\hline & 0.5 & $50.3^{i} \pm 0.1$ & $30^{e} \pm 0.1$ & $62.8^{j} \pm 0.4$ \\
\hline & 1 & $68.5^{\mathrm{k}} \pm 0.1$ & $64.2^{\mathrm{j}} \pm 0.4$ & $85.9^{\circ} \pm 0.5$ \\
\hline & 2 & $93.8^{\mathrm{m}} \pm 0.0$ & $80.3^{\operatorname{lm}} \pm 0.9$ & $95.9^{q} \pm 0.5$ \\
\hline \multirow{5}{*}{ Clove } & 0.1 & $25.2^{f} \pm 0.1$ & $43.7^{g} \pm 1.3$ & $29.3^{d} \pm 0.7$ \\
\hline & 0.2 & $62.4^{j} \pm 0.1$ & $79.7^{1} \pm 0.9$ & $36.6^{f} \pm 0.3$ \\
\hline & 0.5 & $81.2^{\prime} \pm 0.1$ & $100^{\circ} \pm 0.0$ & $65.6^{\mathrm{k}} \pm 0.8$ \\
\hline & 1 & $100^{n} \pm 0.0$ & $105.8^{p} \pm 1.0$ & $92.8^{p} \pm 0.4$ \\
\hline & 2 & $111.2^{\mathrm{q}} \pm 0.7$ & $116.5^{r} \pm 0.8$ & $103.4^{\mathrm{s}} \pm 0.3$ \\
\hline \multirow{5}{*}{ Geranium } & 0.1 & $18.6^{e} \pm 0.1$ & $24.2^{\mathrm{d}} \pm 0.6$ & $20.3^{c} \pm 0.9$ \\
\hline & 0.2 & $43.9^{\mathrm{h}} \pm 0.1$ & $55.3^{\mathrm{h}} \pm 0.3$ & $40^{g} \pm 0.6$ \\
\hline & 0.5 & $81.2^{1} \pm 0.1$ & $70.3^{k} \pm 0.9$ & $62.8^{j} \pm 0.4$ \\
\hline & 1 & $100^{n} \pm 0.0$ & $100^{\circ} \pm 0.0$ & $79.7^{n} \pm 0.3$ \\
\hline & 2 & $107^{\circ} \pm 0.5$ & $114.7^{r} \pm 0.3$ & $100^{r} \pm 0.0$ \\
\hline \multirow{5}{*}{ Lavender } & 0.1 & $6.2^{\mathrm{b}} \pm 0.1$ & $0^{a} \pm 0.0$ & $0^{\mathrm{a}} \pm 0.0$ \\
\hline & 0.2 & $18.7^{e} \pm 0.1$ & $19.7^{c} \pm 0.3$ & $16.6^{b} \pm 0.3$ \\
\hline & 0.5 & $43.7^{\mathrm{h}} \pm 0.1$ & $60.7^{i} \pm 1.2$ & $29.7^{d} \pm 0.3$ \\
\hline & 1 & $62.2^{\mathrm{j}} \pm 0.2$ & $82^{m} \pm 1.2$ & $72.4^{\mathrm{m}} \pm 0.7$ \\
\hline & 2 & $100^{n} \pm 0.0$ & $100^{\circ} \pm 0.0$ & $100^{r} \pm 0.0$ \\
\hline \multirow{5}{*}{ Lemongrass } & 0.1 & $37.5^{9} \pm 0.1$ & $33.7^{f} \pm 0.9$ & $35.9^{f} \pm 0.5$ \\
\hline & 0.2 & $62.3^{j} \pm 0.1$ & $64^{j} \pm 0.6$ & $52.8^{\mathrm{h}} \pm 0.4$ \\
\hline & 0.5 & $100^{n} \pm 0.0$ & $95^{n} \pm 0.6$ & $86.6^{\circ} \pm 0.3$ \\
\hline & 1 & $112.6^{r} \pm 0.4$ & $110.8^{q} \pm 0.4$ & $105.4^{t} \pm 0.4$ \\
\hline & 2 & $118.3^{\mathrm{s}} \pm 0.6$ & $129.2^{t} \pm 0.6$ & $116.6^{\mathrm{u}} \pm 0.3$ \\
\hline \multirow{5}{*}{ Thyme } & 0.1 & $37.4^{\mathrm{g}} \pm 0.1$ & $61^{\mathrm{i}} \pm 1.0$ & $56.1^{i} \pm 0.5$ \\
\hline & 0.2 & $68.9^{k} \pm 0.1$ & $81^{1 \mathrm{~m}} \pm 0.6$ & $70.5^{1} \pm 0.3$ \\
\hline & 0.5 & $93.9^{m} \pm 0.1$ & $100^{\circ} \pm 0.0$ & $100^{r} \pm 0.0$ \\
\hline & 1 & $109.5^{p} \pm 0.3$ & $122.5^{\mathrm{s}} \pm 0.3$ & $120.5^{v} \pm 0.3$ \\
\hline & 2 & $131.5^{t} \pm 0.3$ & $135^{\mathrm{u}} \pm 0.5$ & $143.4^{w} \pm 0.3$ \\
\hline \multicolumn{2}{|c|}{ LSD 0.05} & 8.02 & 8.28 & 7.81 \\
\hline
\end{tabular}


The tested thyme and lemongrass EOs were the most effective significant EOs against the three isolated bacterial species. At the highest concentration $(2 \mu \mathrm{L} / \mathrm{mL})$, the tested thyme EO showed the highest inhibition percentage $(143.4 \%)$ against Serratia odorifera, followed by P. putida (135\%), and Pseudomonas protegens (131.5\%). This result may be due to the presence of thymol, which causes bacterial cell wall damage, as well as carvacrol and thymol sensitizing microbial cell walls, which results in cell wall degradation, cytoplasmic membrane damage, cytoplasm coagulation, membrane protein destruction, proton motive force decrease, and microbial cell dissolution (Nazzaro et al. 2013). Thyme EO has antibacterial activity at very low concentrations $(0.5 \%)$ against almost all rock colonizing bacteria isolated from different archaeological limestone objects, in Egypt (ElBaghdady et al. 2019). The Thymus EO inhibited the growth of Bacillus subtilis from an ancient Egyptian Coptic cellulosic manuscript at a concentration of $0.1 \%$ v/v (Noshyutta et al. 2016).

The tested lemongrass EO, at a concentration of $2 \mu \mathrm{L} / \mathrm{mL}$, exhibited significant inhibition of the three isolated deteriorating bacterial species, ranging from $116.6 \%$ to 129.2\%. The obtained results agreed with Mehmood et al. (2018), who found that lemongrass EO has inhibitory activity against Staphylococcus aureus, Bacillus subtilis, and Escherichia coli. The phenolic compounds in lemongrass EO might be responsible for the antimicrobial activity by changing the permeability of the cell wall, reacting with cell membrane phospholipids, and denaturing the proteins (Klangmuang and Sothornvit 2016). Lemongrass EO penetrates the bacterial cytoplasmic membrane, causing intracellular component leakage and, as a result, cell death (Mishra et al. 2018). The major components of lemongrass EO, i.e., citronellal, citronellol, nerol, and geraniol, increase the membrane fluidity and permeability of the microorganisms, induce cellular lysis, and damage the cytoplasmic membrane integrity of these microorganisms (Cunha et al. 2020).

Moderate antibacterial activity was found in the clove and geranium EOs. It was found that the clove EO damaged the Bacillus sp. membrane, which were taken from the National Archive of the Republic of Cuba and the Historical Archive of the Museum of La Plata in Argentina (Borrego et al. 2012). The hydrophobicity of the clove EO and its components enabled them to distribute into the lipids of the bacterial cell membrane and mitochondria, interfering with these structures. This caused these structures to become more permeable, which affects cell metabolism and finally causes bacterial death (Burt 2004). Citronellol, citronellyl formate, and geraniol are the primary ingredients of geranium EO, and they have an antibacterial impact against Gram-positive bacteria more than Gram-negative bacteria (Boukhatem et al. 2013).

The least efficient essential oils were lavender and black cumin. The obtained data agreed with Yuan et al. (2019), who showed that lavender oil has antifungal, antibacterial and antioxidant properties. The black cumin EO has antimicrobial activity against Gramnegative bacteria due to their active compounds, i.e., carvone, D-limonene, $\alpha$-pinene, and p-cymene (Konuk Takma and Korel 2019).

It was found that there was no difference in the diameter of the inhibition zone against of Bacillus subtilis at all concentrations of Lavandula angustifolia $(5 \mathrm{mg} / \mathrm{mL}, 10$ $\mathrm{mg} / \mathrm{mL}$, and $20 \mathrm{mg} / \mathrm{mL}$ ), where the diameter of the inhibition zone of B. subtilis at the highest concentration (20 mg/mL) was $13.43 \mathrm{~mm}$ (Rashed et al. 2017). Lavender EO showed moderate antibacterial activity, while black cumin oil did not show any inhibitory effect against any of the tested bacterial species (Al-Nabulsi et al. 2020). It was suggested that the redox potential action of black cumin EO could aid in the adsorption and neutralization of free radicals as well as the chelation of metals (Bettaieb et al. 2010). 
The MIC values of the different tested EOs are shown in Table 5. The MICs of the thyme and lemongrass EOs ranged from 0.5 to $2 \mu \mathrm{L} / \mathrm{mL}$ for all the tested deteriorating fungal species, while the MIC values for the three isolated bacterial species ranged from 0.5 to $1 \mu \mathrm{L} / \mathrm{mL}$. The obtained data agreed with Boubaker et al. (2016), who indicated that the Thymus EO showed complete inhibition (100\%) of spore germination for Penicillium sp. at a concentration of $0.5 \mu \mathrm{L} / \mathrm{mL}$. Thyme EO at a concentration of $0.5 \mu \mathrm{L} / \mathrm{mL}$ had a strong inhibitory activity on the growth of Aspergillus sp. (Božik et al. 2017). Lemongrass EO has strong antimicrobial activity with a MIC value of $0.025 \%$ for Staphylococcus aureus and $0.5 \%$ for Escherichia coli (Mendes et al. 2020).

Table 5. Minimum Inhibitory Concentration (MIC) of Six Tested Essential Oils (Black Cumin, Clove, Geranium, Lavender, Lemongrass, and Thyme) on the Isolated Microbial Species from the Ptahshepses Stone Statue from the Saqqara Excavation, Giza, Egypt

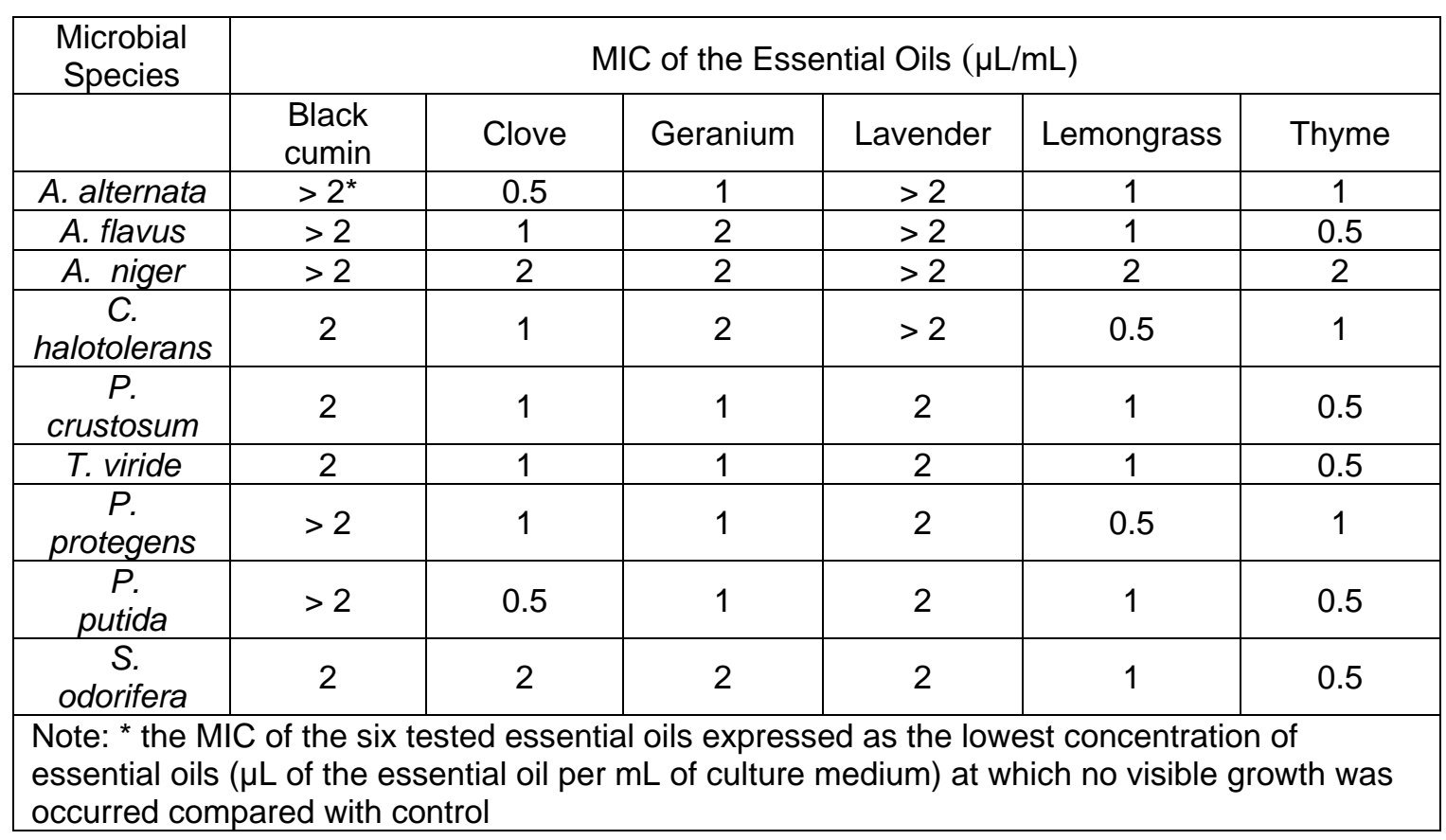

The MIC of the clove EO ranged from 0.5 to $2 \mu \mathrm{L} / \mathrm{mL}$ for all the isolated deteriorating fungal and bacterial species, while the MIC of the geranium EO ranged from 1 to $2 \mu \mathrm{L} / \mathrm{mL}$ for all the isolated deteriorating fungal and bacterial species. The thyme and clove EOs were highly active at a concentration of 0.75 to $1.5 \mathrm{mg} / \mathrm{mL}$ against $P$. fluorescens, E. coli, Serratia marcescens, S. aureus, Micrococcus spp., Sarcina spp., and Bacillus subtilis (Farag et al. 1989). The obtained results agreed with Sienkiewicz et al. (2014), who showed that geranium EO had the greatest antibacterial efficiency against various bacterial species with a MIC ranging from 3.0 to $8.0 \mu \mathrm{L} / \mathrm{mL}$.

The MIC of the tested lavender EO was $2 \mu \mathrm{L} / \mathrm{mL}$ for Penicillium crustosum, Trichoderma viride, $P$. protegens, $P$. putida, and Serratia odorifera, while the MIC for Alternaria alternate, A. flavus, A. niger, and Cladosporium halotolerans was greater than $2 \mu \mathrm{L} / \mathrm{mL}$. The MIC of the black cumin EO was $2 \mu \mathrm{L} / \mathrm{mL}$ for $C$. halotolerans, Penicillium crustosum, Trichoderma viride, and S. odorifera. The inhibitory effect of the black cumin EO against some pathogenic bacterial species had an MIC ranging from 100 to $200 \mu \mathrm{g} / \mathrm{mL}$ 
(Hassanien et al. 2014).

When thymol collaborated with the cell membranes, it affected membrane permeability, which led to a lack of membrane potential with outflows of adenosine 5'triphosphate (ATP), carboxyfluorescein, and potassium ions (Hyldgaard et al. 2012). Thymol also affected many enzymes directly or indirectly that were involved in the synthesis of ATP and destroyed the citrate metabolic pathway (Pasqua et al. 2010). The potency of the cells to improve after exposure to thymol is very low because thymol affects critical energy-generating processes. Thymol damages ergosterol biosynthesis as well as disrupts vesicles and cell membranes in Candida strains because ergosterol regulates membrane asymmetry and fluidity (Hyldgaard et al. 2012). Additionally, thymol showed considerable fungicidal efficiency against $A$. flavus through the reactive oxygen species scavengers.

Found in thyme EO, p-cymene is a monoterpene that has an inadequate antimicrobial efficiency when used alone (Bagamboula et al. 2004). However, it can induce the efficiency of some compounds, e.g., polymyxin B nonapeptide and carvacrol (Rattanachaikunsopon and Phumkhachorn 2010). Several studies have shown that $p$ cymene can act as an alternative impurity in the microbial membrane, which partly disturbs it. As such, $p$-cymene causes the expansion of the membrane and influences the membrane potential of undamaged cells and causes a reduction in the enthalpy and melting temperature of membranes (Cristani et al. 2007). In addition, $p$-cymene can affect protein synthesis and cell motility (Burt Sara et al. 2007).

The lemongrass EO and its citral components are capable of antifungal activity against $A$. niger, Alternaria alternate, Fusarium moniliforme, and $F$. solani via damaging their cell wall and cell membrane to a noticeable degree. In addition, they can cause partial cytoplasm leakage by inhibiting DNA, RNA, protein, and biosynthesis of peptidoglycan as well as interfering with the ergosterol biosynthesis in Candida albicans (Nazzaro et al. 2013).

Eugenol is the fundamental ingredient in clove EO, and its antimicrobial efficiency is related to its ability to interact with proteins and permeabilize the cell membrane (Goñi et al. 2016). Eugenol affects the membranes via the non-distinct permeabilization of the cytoplasmic membrane, which increases the transport of ATP and potassium out of the cells (Hyldgaard et al. 2012). Eugenol causes alterations in the fatty acid profile of Brochotrix thermosphacta, E. coli, Salmonella enterica, and S. aureus (Di Pasqua et al. 2010).

An inhibitory effect was found for EOs relative to the growth and physiological activity of the deteriorating fungal species isolated from three archeological objects found at the Saqqara excavation, Egypt (Geweely et al. 2020). In addition, the antimicrobial activity of gold nanoparticles (AuNPs) in terms of the deterioration of archeological gilded painted cartonnage, from the late period, in Saqqara, Egypt was tested (Afifi et al. 2016).

In conclusion, these essential oils are recommended as they are not toxic to the conservators and cannot cause damage to the surfaces treated.

\section{CONCLUSIONS}

1. Chemical and mechanical preservation are not effective agents for eliminating deteriorating microbial species. Therefore, the primary recommendation of this research is the usage of natural and environmentally-friendly treatments for the 
preservation of stone archaeological objects.

2. The development of natural biocides helps reduce the negative impact of synthetic agents as well as being effective, selective, biodegradable, and less toxic to the environment.

3. Most essential oils have some degree of antimicrobial activity attributable to the presence of terpenoid and phenolic compounds.

4. The obtained results confirmed that the thyme and lemongrass oils were potentially useful for protecting the Ptahshepses stone statue found at the Saqqara excavation, in Giza, Egypt from microbial deterioration.

\section{ACKNOWLEDGMENTS}

This research was funded by the Researchers Supporting Project (RSP2021/123)King Saud University, Riyadh, Saudi Arabia.

\section{REFERENCES CITED}

Abd-Elkader, D. Y., Salem, M. Z. M., Komeil, D. A., Al-Huqail, A. A., Ali, H. M., Salah, A. H., Akrami, M., and Hassan, H.S. (2021). "Post-harvest enhancing and Botrytis cinerea control of strawberry fruits using low cost and eco-friendly natural oils," Agronomy 11(6), 1-22. DOI: 10.3390/agronomy 11061246

Adam, K., Sivropoulou, A., Kokkini, S., Lanaras, T., and Arsenakis, M. (1998). "Antifungal activities of Origanum vulgare subsp. hirtum, Mentha spicata, Lavandula angustifolia, and Salvia fruticosa essential oils against human pathogenic fungi," Journal of Agricultural and Food Chemistry 46(5), 1739-1745. DOI: $10.1021 / \mathrm{jf} 9708296$

Afifi, H. A. M. (2012). "Comparative efficacy of some plant extracts against fungal deterioration of stucco ornaments in the mihrab of Mostafa Pasha Ribate, Cairo, Egypt," American Journal of Biochemistry and Molecular Biology 2(1), 40-47. DOI: 10.3923/ajbmb.2012.40.47

Afifi, H. A. M., and Geweely, N. S. I. (2006). "Analysis and conservation of archaeological limestone relief from fungal deterioration using captan fungicide (case study), Egypt," Egyptian Journal of Biotechnology 22, 378-395.

Afifi, H. A. M., Galal, H. S., and Ali Hassan, R. R. (2020). "Characterization of pharaonic cartonnage from a late period, Saqqara excavations," Pigment \& Resin Technology 49(4), 255-264. DOI: 10.1108/PRT-07-2019-0061

Afifi, H. A. M., Geweely, N. S., Galal, H. S., Abdelrahim, S. A., and Al-Qudsi, F. M. S. (2016). "Antimicrobial activity of gold nanoparticles (AuNPs) on deterioration of archeological gilded painted cartonnage, late period, Saqqara, Egypt," Geomicrobiology Journal 33(6), 578-585. DOI: 10.1080/01490451.2015.1062064

Agarossi, G., Ferrari, R., and Monte, M. (1990). "Biocides in the control of biodeterioration," in: Proceedings of the La Conservazione dei Monumenti nel Bacino del Mediterraneo: atti del 1o Simposio Internazionale, 7-10 June, Bari, Italy.

Aldosari, M. A., Darwish, S. S., Adam, M. A., Elmarzugi, N. A., and Ahmed, S. M. 
(2019). "Using $\mathrm{ZnO}$ nanoparticles in fungal inhibition and self-protection of exposed marble columns in historic sites," Archaeological and Anthropological Sciences 11(7), 3407-3422. DOI:10.1007/s12520-018-0762-Z

Ali, H. M., Elgat, W. A. A. A., El-Hefny, M., Salem, M. Z. M., Taha, A. S., Al Farraj, D. A., Elshikh, M. S., Hatamleh, A. A., and Abdel-Salam, E. M. (2021). "New approach for using of Mentha longifolia L. and Citrus reticulata L. essential oils as woodbiofungicides: GC-MS, SEM, and MNDO quantum chemical studies," Materials 14(6), 1-18. DOI: 10.3390/ma14061361

Ali-Shtayeh, M. S., Jamous, R. M., Abu-Zaitoun, S. Y., Akkawi, R. J., Kalbouneh, S. R., Dudai, N., and Bernstein, N. (2018). "Secondary treated effluent irrigation did not impact chemical composition, and enzyme inhibition activities of essential oils from Origanum syriacum var. syriacum," Industrial Crops and Products 111, 775-786. DOI: 10.1016/j.indcrop.2017.11.055

Al-Nabulsi, A. A., Osaili, T. M., Olaimat, A. N., Almasri, W. E., Ayyash, M., Al-Holy, M. A., Jaradat, Z. W., Obaid, R. S., and Holley, R. A. (2020). "Inactivation of Salmonella spp. in tahini using plant essential oil extracts," Food Microbiology 86, 19. DOI: $10.1016 /$ j.fm.2019.103338

Badawy, M. E. I., Kherallah, I. E. A., Mohareb, A. S. O., Salem, M. Z. M., and Yousef, H. A. (2017). "Chemical composition and antifungal activity of essential oils isolated from Cupressus sempervirens L. and Juniperus phoenicea L. grown in Al-Jabel AlAkhdar region, Libya against Botrytis cinerea," The Natural Products Journal 7(4), 298-308. DOI: 10.2174/2210315507666170530092645

Bagamboula, C. F., Uyttendaele, M., and Debevere, J. (2004). "Inhibitory effect of thyme and basil essential oils, carvacrol, thymol, estragol, linalool and p-cymene towards Shigella sonnei and S. flexneri," Food Microbiology 21(1), 33-42. DOI: 10.1016/S0740-0020(03)00046-7

Bard, K. A. (2005). Encyclopedia of the Archaeology of Ancient Egypt, Routledge, Oxfordshire, England.

Behiry, S. I., El-Hefny, M., and Salem, M. Z. M. (2020). "Toxicity effects of Eriocephalus africanus L. leaf essential oil against some molecularly identified phytopathogenic bacterial strains," Natural Product Research 34(23), 3394-3398. DOI: 10.1080/14786419.2019.1566824

Bettaieb, I., Bourgou, S., Wannes, W. A., Hamrouni, I., Limam, F., and Marzouk, B. (2010). "Essential oils, phenolics, and antioxidant activities of different parts of cumin (Cuminum cyminum L.)," Journal of Agricultural and Food Chemistry 58(19), 10410-10418. DOI: 10.1021/jf102248j

Bhore, S. J., Ravichantar, N., and Loh, C. Y. (2010). "Screening of endophytic bacteria isolated from leaves of Sambung nyawa [Gynura procumbens (Lour.) Merr.] for cytokinin-like compounds," Bioinformation 5(5), 191-197. DOI: 10.6026/97320630005191

Boer, W. d., Folman, L. B., Summerbell, R. C., and Boddy, L. (2005). "Living in a fungal world: impact of fungi on soil bacterial niche development," FEMS Microbiology Reviews 29(4), 795-811. DOI: 10.1016/j.femsre.2004.11.005

Borrego, S., Valdés, O., Vivar, I., Lavin, P., Guiamet, P., Battistoni, P., Saravia, S. G. d., and Borges, P. (2012). "Essential oils of plants as biocides against microorganisms isolated from Cuban and Argentine documentary heritage," ISRN Microbiology 2012, 1-8. DOI: $10.5402 / 2012 / 826786$

Boubaker, H., Karim, H., El Hamdaoui, A., Msanda, F., Leach, D., Bombarda, I., 
Vanloot, P., Abbad, A., Boudyach, E. H., and Aoumar, A. A. B. (2016). "Chemical characterization and antifungal activities of four Thymus species essential oils against postharvest fungal pathogens of citrus," Industrial Crops and Products 86, 95-101. DOI: 10.1016/j.indcrop.2016.03.036

Boukhatem, M. N., Kameli, A., and Saidi, F. (2013). "Essential oil of Algerian rosescented geranium (Pelargonium graveolens): Chemical composition and antimicrobial activity against food spoilage pathogens," Food Control 34(1), 208213. DOI: 10.1016/j.foodcont.2013.03.045

Božik, M., Císarová, M., Tančinová, D., Kouřimská, L., Hleba, L., and Klouček, P. (2017). "Selected essential oil vapours inhibit growth of Aspergillus spp. in oats with improved consumer acceptability," Industrial Crops and Products 98, 146-152. DOI: 10.1016/j.indcrop.2016.11.044

Burt, S. (2004). "Essential oils: Their antibacterial properties and potential applications in foods - A review," International Journal of Food Microbiology 94(3), 223-253. DOI: 10.1016/j.ijfoodmicro.2004.03.022

Burt, S. A., Zee, R. v. d., Koets, A. P., Graaff, A. M. d., Knapen, F. v., Gaastra, W., Haagsman, H. P., and Veldhuizen, E. J. A. (2007). "Carvacrol induces heat shock protein 60 and inhibits synthesis of flagellin in Escherichia coli O157:H7," Applied and Environmental Microbiology 73(14), 4484-4490. DOI: 10.1128/AEM.00340-07

Caple, C. (2001). "Degradation, investigation and preservation of archaeological evidence," in: Handbook of Archaeological Sciences, D. Brothwell, and M. Pollard (eds.), John Wiley, Hoboken, NJ.

Carrillo-González, R., Martínez-Gómez, M. A., González-Chávez, M. d. C. A., and Mendoza Hernández, J. C. (2016). "Inhibition of microorganisms involved in deterioration of an archaeological site by silver nanoparticles produced by a green synthesis method," Science of The Total Environment 565, 872-881. DOI: 10.1016/j.scitotenv.2016.02.110

Casadio, F., and Toniolo, L. (2001). "The analysis of polychrome works of art: 40 years of infrared spectroscopic investigations," Journal of Cultural Heritage 2(1), 71-78. DOI: $10.1016 / \mathrm{S} 1296-2074(01) 01107-4$

Clark, D. E., and Zoitos, B. K. (1992). Corrosion of Glass, Ceramics and Ceramic Superconductors: Principles, Testing, Characterization and Applications, Noyes Publications, Park Ridge, NJ.

Colao, F., Fantoni, R., Fiorani, L., Palucci, A., and Gomoiu, I. (2005). "Compact scanning lidar fluorosensor for investigations of biodegradation on ancient painted surfaces," Journal of Optoelectronics and Advanced Materials 7(6), 3197-3208.

Corte, A. M., Ferroni, A., and Salvo, V. S. (2003). "Isolation of fungal species from test samples and maps damaged by foxing, and correlation between these species and the environment," International Biodeterioration \& Biodegradation 51(3), 167-173. DOI: 10.1016/S0964-8305(02)00137-3

Cowan, S. T. (2003). Cowan and Steel's Manual for the Identification of Medical Bacteria, Cambridge University Press, Cambridge, United Kingdom.

Cowan, S. T., and Steel, K. J. (1965). Manual for the Identification of Medical Bacteria, Cambridge University Press, Cambridge, United Kingdom.

Cristani, M., D'Arrigo, M., Mandalari, G., Castelli, F., Sarpietro, M. G., Micieli, D., Venuti, V., Bisignano, G., Saija, A., and Trombetta, D. (2007). "Interaction of four monoterpenes contained in essential oils with model membranes: Implications for their antibacterial activity," Journal of Agricultural and Food Chemistry 55(15), 
6300-6308. DOI: 10.1021/jf070094x

Cunha, B. G., Duque, C., Caiaffa, K. S., Massunari, L., Catanoze, I. A., Santos, D. M. d., Oliveira, S. H. P. d., and Guiotti, A. M. (2020). "Cytotoxicity and antimicrobial effects of citronella oil (Cymbopogon nardus) and commercial mouthwashes on $S$. aureus and C. albicans biofilms in prosthetic materials," Archives of Oral Biology 109, 1-10. DOI: 10.1016/j.archoralbio.2019.104577

Custódio, J. B. A., Ribeiro, M. V., Silva, F. S. G., Machado, M., and Sousa, M. C. (2011). "The essential oils component $p$-cymene induces proton leak through Fo-ATP synthase and uncoupling of mitochondrial respiration," Journal of Experimental Pharmacology 3, 69-76. DOI: 10.2147/JEP.S16387

Daniels, V. (1989). "Oxidative damage and the preservation of organic artefacts," Free Radical Research Communications 5(4-5), 213-220. DOI: 10.3109/10715768909074703

Doronina, N. V., Krauzova, V. I., and Trotsenko, Y. A. (1997). “Methylophaga limanica sp. nov. : A new species of moderately halophilic, aerobic, methylotrophic bacteria," Microbiology 66(4), 434-439.

Doronina, N., Darmaeva, T., and Trotsenko, Y. (2003). “Methylophaga natronica sp. nov., a new alkaliphilic and moderately halophilic, restricted-facultatively methylotrophic bacterium from soda lake of the southern Transbaikal region," Systematic and Applied Microbiology 26(3), 382-389. DOI: 10.1078/072320203322497419

ElBaghdady, K. Z., Tolba, S. T., and Houssien, S. S. (2019). "Biogenic deterioration of Egyptian limestone monuments: Treatment and conservation," Journal of Cultural Heritage 38, 118-125. DOI: 10.1016/j.culher.2019.02.005

Elgat, W. A. A. A., Kordy, A. M., Böhm, M., Černý, R., Abdel-Megeed, A., and Salem, M. Z. M. (2020). "Eucalyptus camaldulensis, Citrus aurantium, and Citrus sinensis essential oils as antifungal activity against Aspergillus flavus, Aspergillus niger, Aspergillus terreus, and Fusarium culmorum," Processes 8(8), 1-16. DOI: 10.3390/pr8081003

El-Hefny, M., Elgat, W. A. A. A., Al-Huqail, A. A., and Ali, H. M. (2019). "Essential and recovery oils from Matricaria chamomilla flowers as environmentally friendly fungicides against four fungi isolated from cultural heritage objects," Processes 7(11), 1-12. DOI: 10.3390/pr7110809

Elserogy, A., Kanan, G., Hussein, E., and Khersis, S. A. (2016). "Isolation, characterization and treatment of microbial agents responsible for the deterioration of archaeological objects in three Jordanian museums," Mediterranean Archaeology and Archaeometry 16(1), 117-126. DOI: 10.5281/zenodo.35525

Escudero, V., and Mendoza, R. (2005). "Seasonal variation of arbuscular mycorrhizal fungi in temperate grasslands along a wide hydrologic gradient," Mycorrhiza 15(4), 291-299. https://doi.org/10.1007/s00572-004-0332-3

Farag, R. S., Daw, Z. Y., Hewedi, F. M., and El-Baroty, G. S. A. (1989). “Antimicrobial activity of some Egyptian spice essential oils," Journal of Food Protection 52(9), 665-667. DOI: 10.4315/0362-028x-52.9.665

Geweely, N. S., Afifi, H. A. M., Abdelrahim, S. A., and Alakilli, S. Y. M. (2014). "Novel comparative efficiency of ozone and gamma sterilization on fungal deterioration of archeological painted coffin, Saqqara excavation, Egypt," Geomicrobiology Journal 31(6), 529-539. DOI: 10.1080/01490451.2013.806612

Geweely, N. S., Afifi, H. A., Ibrahim, D. M., and Soliman, M. M. (2019). "Efficacy of 
essential oils on fungi isolated from archaeological objects in Saqqara excavation, Egypt," Geomicrobiology Journal 36(2), 148-168. DOI:

10.1080/01490451.2018.1520938

Geweely, N. S., Afifi, H. A., Ibrahim, D. M., and Soliman, M. M. (2020). “Inhibitory effect of essential oils on growth and physiological activity of deteriorated fungal species isolated from three archeological objects, Saqqara excavation, Egypt," Geomicrobiology Journal 37(6), 520-533. DOI: 10.1080/01490451.2020.1731021

Goñi, M. L., Gañán, N. A., Strumia, M. C., and Martini, R. E. (2016). "Eugenol-loaded LLDPE films with antioxidant activity by supercritical carbon dioxide impregnation," The Journal of Supercritical Fluids 111, 28-35. DOI: 10.1016/j.supflu.2016.01.012

Gorbushina, A. A., Heyrman, J., Dornieden, T., Gonzalez-Delvalle, M., Krumbein, W. E., Laiz, L., Petersen, K., Saiz-Jimenez, C., and Swings, J. (2004). "Bacterial and fungal diversity and biodeterioration problems in mural painting environments of St. Martins church (Greene-Kreiensen, Germany)," International Biodeterioration \& Biodegradation 53(1), 13-24. DOI: 10.1016/j.ibiod.2003.07.003

Grabek-Lejko, D., Tekiela, A., and Kasprzyk, I. (2017). "Risk of biodeterioration of cultural heritage objects, stored in the historical and modern repositories in the Regional Museum in Rzeszow (Poland). A case study," International Biodeterioration \& Biodegradation 123, 46-55. DOI: 10.1016/j.ibiod.2017.05.028

Hadjilouka, A., Mavrogiannis, G., Mallouchos, A., Paramithiotis, S., Mataragas, M., and Drosinos, E. H. (2017). "Effect of lemongrass essential oil on Listeria monocytogenes gene expression,” LWT 77, 510-516. DOI: 10.1016/j.lwt.2016.11.080

Hamad, Y. K., Abobakr, Y., Salem, M. Z., Ali, H. M., Al-Sarar, A. S., and Al-Zabib, A. A. (2019). "Activity of plant extracts/essential oils against three plant pathogenic fungi and mosquito larvae: GC/MS analysis of bioactive compounds," BioResources 14(2), 4489-4511. DOI: 10.15376/biores.14.2.4489-4511

Hassanien, M. F. R., Mahgoub, S. A., and El-Zahar, K. M. (2014). "Soft cheese supplemented with black cumin oil: Impact on food borne pathogens and quality during storage," Saudi Journal of Biological Sciences 21(3), 280-288. DOI: 10.1016/j.sjbs.2013.10.005

Hyldgaard, M., Mygind, T., and Meyer, R. (2012). "Essential oils in food preservation: Mode of action, synergies, and interactions with food matrix components," Frontiers in Microbiology 3(12), 1-24. DOI: 10.3389/fmicb.2012.00012

Ishii, H. (2017). "Monitoring of fungicide resistance in fungi: Biological to biotechnological approaches," in: Molecular Methods in Plant Pathology, R. P. Singh, and U. S. Singh (ed.), CRC Press, Boca Raton, FL.

Johnson, N. C., Tilman, D., and Wedin, D. (1992). "Plant and soil controls on mycorrhizal fungal communities," Ecology 73(6), 2034-2042. DOI: 10.2307/1941453

Kavita, S., Verma, K. P., and Motilal (2011). "Fungal involvement in biodeterioration of ancient monuments: Problem and prospects," Journal of Phytology 3(4), 15-17.

Kern, M. E., and Blevins, K. S. (1997). "Laboratory procedures for fungal culture and isolation," in: Medical Mycology: A Self-Instructional Text, M. E. Kern, and K. S. Blevins (ed.), F. A. Davis, Philadelphia, PA.

Klangmuang, P., and Sothornvit, R. (2016). "Barrier properties, mechanical properties and antimicrobial activity of hydroxypropyl methylcellulose-based nanocomposite films incorporated with Thai essential oils," Food Hydrocolloids 61, 609-616. DOI: 10.1016/j.foodhyd.2016.06.018

Lane, D. (1991). “16S/23S rRNA sequencing,” in: Nucleic Acid Techniques in Bacterial 
Systematics, E. Stackebrandt, and M. Goodfellow (ed.), Wiley, Hoboken, NJ.

Lee, G., Kim, Y., Kim, H., Beuchat, L. R., and Ryu, J.-H. (2018). “Antimicrobial activities of gaseous essential oils against Listeria monocytogenes on a laboratory medium and radish sprouts," International Journal of Food Microbiology 265, 49-54. DOI: 10.1016/j.ijfoodmicro.2017.11.001

Lee, M. W. (2004). "Review: Fungal facts: Solving fungal problems in heritage collections," Journal of the American Institute for Conservation 43(1), 114-116. DOI: $10.2307 / 3179856$

Luther, M., Parry, J., Moore, J., Meng, J., Zhang, Y., Cheng, Z., and Yu, L. (2007). "Inhibitory effect of Chardonnay and black raspberry seed extracts on lipid oxidation in fish oil and their radical scavenging and antimicrobial properties," Food Chemistry 104(3), 1065-1073. DOI: 10.1016/j.foodchem.2007.01.034

Mansour, M. M. A., El-Hefny, M., Salem, M. Z. M., and Ali, H. M. (2020). "The biofungicide activity of some plant essential oils for the cleaner production of model linen fibers similar to those used in ancient Egyptian mummification," Processes 8(1), 1-19. DOI: 10.3390/pr8010079

Mansour, M. M. A., Salem, M. Z. M., Hassan, R. R. A., Ali, H. M., Al Farraj, D. A., and Elshikh, M. S. (2021). "Antifungal potential of three natural oils and their effects on the thermogravimetric and chromatic behaviors when applied to historical paper and various commercial paper sheets," BioResources 16(1), 492-514. DOI:

10.15376/biores.16.1.492-514

Marco, A., Santos, S., Caetano, J., Pintado, M., Vieira, E., and Moreira, P. R. (2020). "Basil essential oil as an alternative to commercial biocides against fungi associated with black stains in mural painting," Building and Environment 167, 1-9. DOI: 10.1016/j.buildenv.2019.106459

Mehmood, R. Q. F. A. T., Shahid, M., and Zahoor, S. (2018). "Variations in chemical composition, antimicrobial and haemolytic activities of peel essential oils from three local Citrus cultivars," Pure and Applied Biology 7(1), 282-291. DOI: 10.19045/bspab.2018.70034

Mellon, J. E., Cotty, P. J., and Dowd, M. K. (2007). "Aspergillus flavus hydrolases: Their roles in pathogenesis and substrate utilization," Applied Microbiology and Biotechnology 77(3), 497-504. DOI: 10.1007/s00253-007-1201-8

Mendes, J. F., Norcino, L. B., Martins, H. H. A., Manrich, A., Otoni, C. G., Carvalho, E. E. N., Piccoli, R. H., Oliveira, J. E., Pinheiro, A. C. M., and Mattoso, L. H. C. (2020). "Correlating emulsion characteristics with the properties of active starch films loaded with lemongrass essential oil," Food Hydrocolloids 100, 1-11. DOI: 10.1016/j.foodhyd.2019.105428

Mishra, D., Khare, P., Singh, D. K., Luqman, S., Ajaya Kumar, P. V., Yadav, A., and Das, T., Saikia, B. K. (2018). "Retention of antibacterial and antioxidant properties of lemongrass oil loaded on cellulose nanofibre-poly ethylene glycol composite," Industrial Crops and Products 114, 68-80. DOI: 10.1016/j.indcrop.2018.01.077

Mosa, W. F. A., El-Shehawi, A. M., Mackled, M. I., Salem, M. Z. M., Ghareeb, R. Y., Hafez, E. E., Behiry, S. I., and Abdelsalam, N. R. (2021). "Productivity performance of peach trees, insecticidal and antibacterial bioactivities of leaf extracts as affected by nanofertilizers foliar application," Scientific Reports 11(1), 1-19. DOI: 10.1038/s41598-021-89885-y

Moustafa, M. A. M., Awad, M., Amer, A., Hassan, N. N., Ibrahim, E.-D. S., Ali, H. M., Akrami, M., and Salem, M.Z.M. (2021). "Insecticidal activity of lemongrass essential 
oil as an eco-friendly agent against the black cutworm Agrotis ipsilon (Lepidoptera: Noctuidae)," Insects 12(8), 1-12. DOI: 10.3390/insects12080737

Nazzaro, F., Fratianni, F., Martino, L. D., Coppola, R., and Feo, V. D. (2013). "Effect of essential oils on pathogenic bacteria," Pharmaceuticals 6(12), 1451-1474. DOI: 10.3390/ph6121451

Netzker, T., Fischer, J., Weber, J., Mattern, D. J., König, C. C., Valiante, V., Schroeckh, V. and Brakhage, A. A. (2015). "Microbial communication leading to the activation of silent fungal secondary metabolite gene clusters," Frontiers in Microbiology 6(299), 1-13. DOI: 10.3389/fmicb.2015.00299

Noshyutta, W., Osman, E., and Mansour, M. (2016). "An investigation of the biological fungicidal activity of some essential oils used as preservatives for a $19^{\text {th }}$ century Egyptian Coptic cellulosic manuscript," International Journal of Conservation Science 7(1), 41-56.

Okla, M. K., Alamri, S. A., Salem, M. Z. M., Ali, H. M., Behiry, S. I., Nasser, R. A., Alaraidh, I. A., Al-Ghtani, S. M., and Soufan, W. (2019). "Yield, phytochemical constituents, and antibacterial activity of essential oils from the leaves/twigs, branches, branch wood, and branch bark of sour orange (Citrus aurantium L.)," Processes 7(6), 1-15. DOI: 10.3390/pr7060363

Omonijo, F. A., Ni, L., Gong, J., Wang, Q., Lahaye, L., and Yang, C. (2018). "Essential oils as alternatives to antibiotics in swine production," Animal Nutrition 4(2), 126136. DOI: 10.1016/j.aninu.2017.09.001

Ortiz, R., Navarrete, H., Navarrete, J., Párraga, M., Carrasco, I., Vega, E. d. 1., Ortiz, M., Herrera, P., and Blanchette, R. A. (2014). "Deterioration, decay and identification of fungi isolated from wooden structures at the Humberstone and Santa Laura saltpeter works: A world heritage site in Chile," International Biodeterioration \& Biodegradation 86(Part C), 309-316. DOI: 10.1016/j.ibiod.2013.10.002

Oussalah, M., Caillet, S., Saucier, L., and Lacroix, M. (2007). "Inhibitory effects of selected plant essential oils on the growth of four pathogenic bacteria: E. coli O157:H7, Salmonella Typhimurium, Staphylococcus aureus and Listeria monocytogenes," Food Control 18(5), 414-420. DOI: 10.1016/j.foodcont.2005.11.009

Pandey, A. K., Shrivastav, A., Bhatnagar, P., Sarsaiya, S., and Awasthi, M. K. (2011). "Diversity of monument deterioration-causing fungi at Gwalior Fort (MP) India," Annals of Environmental Science 5, 35-40.

Parenicová, L., Benen, J. A., Kester, H. C., and Visser, J. (2000). "pgaA and pgaB encode two constitutively expressed endopolygalacturonases of Aspergillus niger," Biochemical Journal 345(3), 637-644. DOI: 10.1042/bj3450637

Pasqua, R. D., Mamone, G., Ferranti, P., Ercolini, D., and Mauriello, G. (2010). "Changes in the proteome of Salmonella enterica serovar Thompson as stress adaptation to sublethal concentrations of thymol," Proteomics 10(5), 1040-1049. DOI: $10.1002 /$ pmic.200900568

Pinna, D., Galeotti, M., Perito, B., Daly, G., and Salvadori, B. (2018). "In situ long-term monitoring of recolonization by fungi and lichens after innovative and traditional conservative treatments of archaeological stones in Fiesole (Italy)," International Biodeterioration \& Biodegradation 132, 49-58. DOI: 10.1016/j.ibiod.2018.05.003 Radford, A. (1991). "Methods in yeast genetics - A laboratory course manual by M Rose, F Winston and P Hieter. pp 198. Cold Spring Harbor Laboratory Press, Cold Spring Harbor, New York. 1990. \$34 ISBN 0-87969-354-1,” Biochemistry and Molecular Biology Education 19(2), 101-102. DOI: 10.1016/0307-4412(91)90039-B 
Rakotonirainy, M. S., and Lavédrine, B. (2005). "Screening for antifungal activity of essential oils and related compounds to control the biocontamination in libraries and archives storage areas," International Biodeterioration \& Biodegradation 55(2), 141 147. DOI: 10.1016/j.ibiod.2004.10.002

Rashed, M. M. A., Tong, Q., Nagi, A., Li, J., Khan, N. U., Chen, L., Rotail, A., and Bakry, A. M. (2017). "Isolation of essential oil from Lavandula angustifolia by using ultrasonic-microwave assisted method preceded by enzymolysis treatment, and assessment of its biological activities," Industrial Crops and Products 100, 236-245. DOI: 10.1016/j.indcrop.2017.02.033

Rashid, T. S., Sijam, K., Awla, H. K., Saud, H. M., and Kadir, J. (2016). "Pathogenicity assay and molecular identification of fungi and bacteria associated with diseases of tomato in Malaysia," American Journal of Plant Sciences 7(6), 949-957. DOI:10.4236/ajps.2016.76090

Rattanachaikunsopon, P., and Phumkhachorn, P. (2010). "Assessment of factors influencing antimicrobial activity of carvacrol and cymene against Vibrio cholerae in food," Journal of Bioscience and Bioengineering 110(5), 614-619. DOI: 10.1016/j.jbiosc.2010.06.010

Riemann, L., Steward, G. F., and Azam, F. (2000). "Dynamics of bacterial community composition and activity during a mesocosm diatom bloom," Applied and Environmental Microbiology 66(2), 578-587. DOI: 10.1128/AEM.66.2.578-587.2000

Roilides, E., and Iosifidis, E. (2019). "Acquired resistance in fungi: How large is the problem?," Clinical Microbiology and Infection 25(7), 790-791. DOI: 10.1016/j.cmi.2019.02.018

Rota, M. C., Herrera, A., Martínez, R. M., Sotomayor, J. A., and Jordán, M. J. (2008). "Antimicrobial activity and chemical composition of Thymus vulgaris, Thymus zygis and Thymus hyemalis essential oils," Food Control 19(7), 681-687. DOI: 10.1016/j.foodcont.2007.07.007

Sahal, G., Woerdenbag, H. J., Hinrichs, W. L. J., Visser, A., Tepper, P. G., Quax, W. J., Mei, H. C. v. d., and Bilkay, I. S. (2020). "Antifungal and biofilm inhibitory effect of Cymbopogon citratus (lemongrass) essential oil on biofilm forming by Candida tropicalis isolates; an in vitro study," Journal of Ethnopharmacology 246, 1-9. DOI: 10.1016/j.jep.2019.112188

Sakr, A. A., Ghaly, M. F., and Abdel-Haliem, M. E.-S. F. (2012). "The efficacy of specific essential oils on yeasts isolated from the royal tomb paintings at Tanis, Egypt," International Journal of Conservation Science 3(2), 87-92.

Salem, M. Z. M., Ali, M. F., Mansour, M. M. A., Ali, H. M., Moneim, E. M. A., and Abdel-Megeed, A. (2020). "Anti-termitic activity of three plant extracts, chlorpyrifos, and a bioagent compound (Protecto) against termite Microcerotermes eugnathus Silvestri (Blattodea: Termitidae) in Egypt," Insects 11(11), 1-15. DOI: 10.3390/insects11110756

Salem, M. Z. M., El-Hefny, M., Ali, H. M., Abdel-Megeed, A., El-Settawy, A. A. A., Böhm, M., Mansour, M. M. A., and Salem, A. Z. M. (2021a). "Plants-derived bioactives: Novel utilization as antimicrobial, antioxidant and phytoreducing agents for the biosynthesis of metallic nanoparticles," Microbial Pathogenesis 158, 1-18. DOI: $10.1016 /$ j.micpath.2021.105107

Salem, M. Z. M., Mohamed, A. A., Ali, H. M., and Farraj, D. A. A. (2021b). "Characterization of phytoconstituents from alcoholic extracts of four woody species and their potential uses for management of six Fusarium oxysporum isolates 
identified from some plant hosts," Plants 10(7), 1-17. DOI: 10.3390/plants10071325

Samson, R. A., Hoekstra, E. S., and Van Oorschot, C. A. (1981). Introduction to Foodborne Fungi, Centraalbureau voor Schimmelcultures, Utrecht, Netherlands.

Santos, J. F. S. d., Rocha, J. E., Bezerra, C. F., Silva, M. K. d. N., Matos, Y. M. L. S. d., Freitas, T. S. d., Santos, A. T. L. d., Cruz, R. P. d., Machado, A. J. T., Rodrigues, T. H. S., et al. (2018). "Chemical composition, antifungal activity and potential antivirulence evaluation of the Eugenia uniflora essential oil against Candida spp.," Food Chemistry 261, 233-239. DOI: 10.1016/j.foodchem.2018.04.015

Scheerer, S., Ortega-Morales, O., and Gaylarde, C. (2009). "Chapter 5 microbial deterioration of stone monuments-An updated overview," Advances in Applied Microbiology 66, 97-139. DOI: 10.1016/S0065-2164(08)00805-8

Sharma, A., Sharma, N. K., Srivastava, A., Kataria, A., Dubey, S., Sharma, S., and Kundu, B. (2018). "Clove and lemongrass oil based non-ionic nanoemulsion for suppressing the growth of plant pathogenic Fusarium oxysporum f.sp. lycopersici," Industrial Crops and Products 123, 353-362. DOI: 10.1016/j.indcrop.2018.06.077

Sienkiewicz, M., Głowacka, A., Kowalczyk, E., Wiktorowska-Owczarek, A., JóźwiakBębenista, M., and Łysakowska, M. (2014). "The biological activities of cinnamon, geranium and lavender essential oils," Molecules 19(12), 20929-20940. DOI: 10.3390/molecules 191220929

Singh, G., Marimuthu, P., Heluani, C. S. d., and Catalan, C. (2005). "Chemical constituents and antimicrobial and antioxidant potentials of essential oil and acetone extract of Nigella sativa seeds," Journal of the Science of Food and Agriculture 85(13), 2297-2306. DOI: 10.1002/jsfa.2255

Soffritti, I., D’Accolti, M., Lanzoni, L., Volta, A., Bisi, M., Mazzacane, S., and Caselli, E. (2019). "The potential use of microorganisms as restorative agents: An update," Sustainability 11(14), 1-17. DOI: 10.3390/su11143853

Sterflinger, K. (2010). "Fungi: Their role in deterioration of cultural heritage," Fungal Biology Reviews 24(1-2), 47-55. DOI: 10.1016/j.fbr.2010.03.003

Strzelczyk, A. B. (2004). "Observations on aesthetic and structural changes induced in Polish historic objects by microorganisms." International Biodeterioration \& Biodegradation 53(3), 151-156. DOI: 10.1016/S0964-8305(03)00088-X

Takma, D. K., and Korel, F. (2019). "Active packaging films as a carrier of black cumin essential oil: Development and effect on quality and shelf-life of chicken breast meat," Food Packaging and Shelf Life 19, 210-217. DOI: 10.1016/j.fpsl.2018.11.002

Urzì, C., Lisi, S., Criseo, G., and Pernice, A. (1991). "Adhesion to and degradation of marble by a micrococcus strain isolated from it," Geomicrobiology Journal 9(2-3), 81-90. DOI: $10.1080 / 01490459109385990$

Veneranda, M., Blanco-Zubiaguirre, L., Roselli, G., Girolami, G. D., Castro, K., and Madariaga, J. M. (2018). "Evaluating the exploitability of several essential oils constituents as a novel biological treatment against cultural heritage biocolonization," Microchemical Journal 138, 1-6. DOI: 10.1016/j.microc.2017.12.019

Veneranda, M., Prieto-Taboada, N., Vallejuelo, S. F.-O. d., Maguregui, M., Morillas, H., Marcaida, I., Castro, K.; Madariaga, J. M., and Osanna, M. (2017). "Biodeterioration of Pompeian mural paintings: Fungal colonization favoured by the presence of volcanic material residues," Environmental Science and Pollution Research 24(24), 19599-19608. DOI: 10.1007/s11356-017-9570-8

Vos, P., Garrity, G., Jones, D., Krieg, N. R., Ludwig, W., Rainey, F. A., Schleifer, K.-H., and Whitman, W. (2011). Bergey's Manual of Systematic Bacteriology: Volume 3: 
The Firmicutes, Springer, New York, NY.

White, T. J., Bruns, T., Lee, S., and Taylor, J. (1990). "38 - Amplification and direct sequencing of fungal ribosomal RNA genes for phylogenetics," in: PCR Protocols: A Guide to Methods and Applications, M. A. Innis, D. H. Gelfand, J. J. Sninsky, and T. J. White (ed.), Academic Press, Cambridge, MA.

Xie, Y., Wang, Z., Huang, Q., and Zhang, D. (2017). "Antifungal activity of several essential oils and major components against wood-rot fungi," Industrial Crops and Products 108, 278-285. DOI: 10.1016/j.indcrop.2017.06.041

Yuan, C., Wang, Y., Liu, Y., and Cui, B. (2019). "Physicochemical characterization and antibacterial activity assessment of lavender essential oil encapsulated in hydroxypropyl-beta-cyclodextrin," Industrial Crops and Products 130, 104-110. DOI: 10.1016/j.indcrop.2018.12.067

Zeilinger, S., Gruber, S., Bansal, R., and Mukherjee, P. K. (2016). "Secondary metabolism in Trichoderma - Chemistry meets genomics," Fungal Biology Reviews 30(2), 74-90. DOI: 10.1016/j.fbr.2016.05.001

Zhang, G., Gong, C., Gu, J., Katayama, Y., Someya, T., and Gu, J.-D. (2019). "Biochemical reactions and mechanisms involved in the biodeterioration of stone world cultural heritage under the tropical climate conditions," International Biodeterioration \& Biodegradation 143, 1-8. DOI: 10.1016/j.ibiod.2019.104723

Zhang, J.-G., Li, Q.-M., Thakur, K., Faisal, S., and Wei, Z.-J. (2017). “A possible watersoluble inducer for synthesis of cellulase in Aspergillus niger," Bioresource Technology 226, 262-266. DOI: 10.1016/j.biortech.2016.12.028

Zore, G. B., Thakre, A. D., Rathod, V., and Karuppayil, S. M. (2011). "Evaluation of anti-Candida potential of geranium oil constituents against clinical isolates of Candida albicans differentially sensitive to fluconazole: inhibition of growth, dimorphism and sensitization," Mycoses 54(4), e99-e109. DOI: 10.1111/j.14390507.2009.01852.x

Article submitted: September 12, 2021; Peer review completed: November 14, 2021; Revised version received and accepted: November 22, 2021; Published: November 30, 2021.

DOI: 10.15376/biores.17.1.543-573 


\section{APPENDIX}

\section{Supplementary Materials}

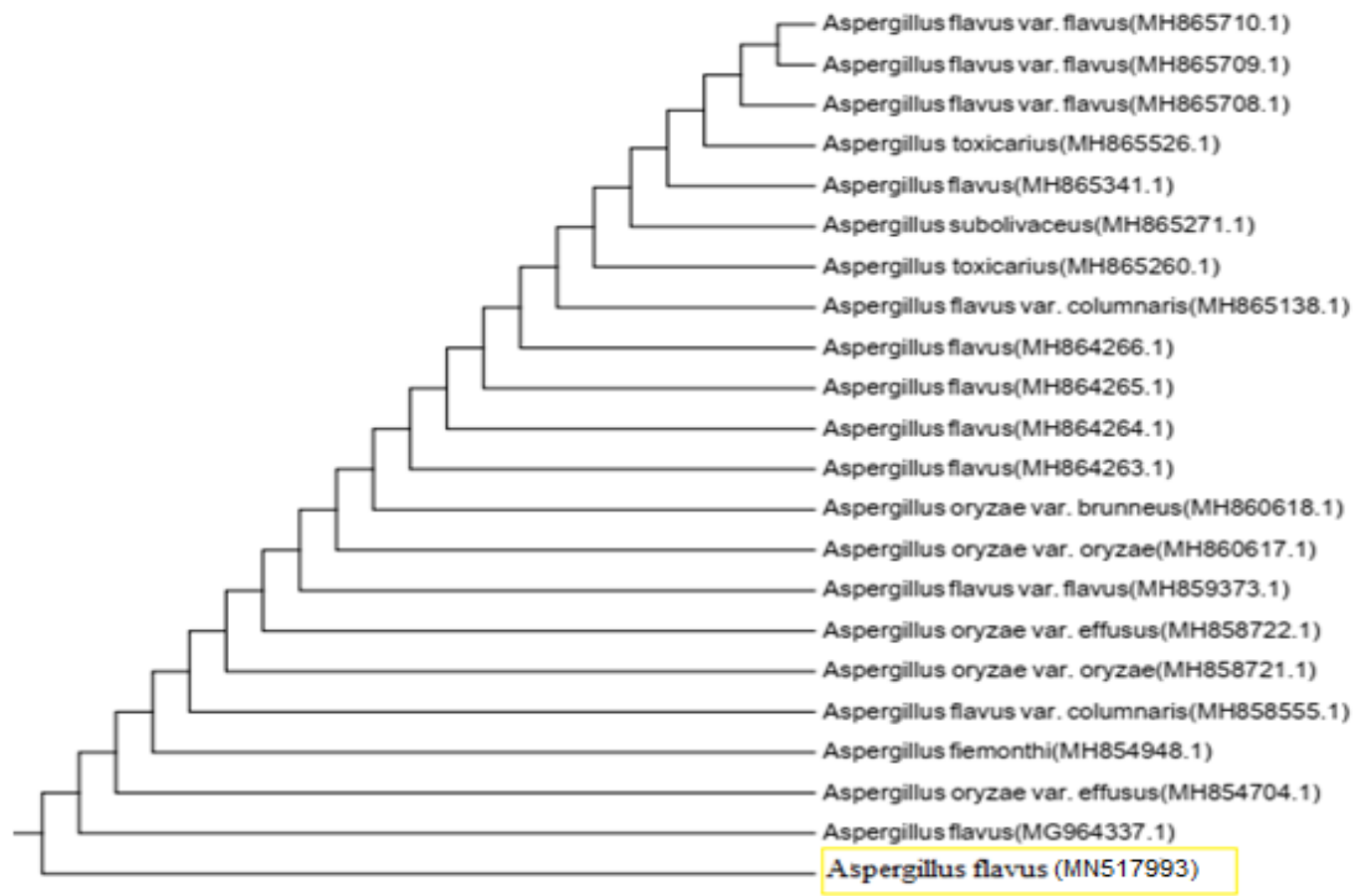

Fig. S1. Phylogenetic analysis tree of Aspergillus flavus (MN517993)

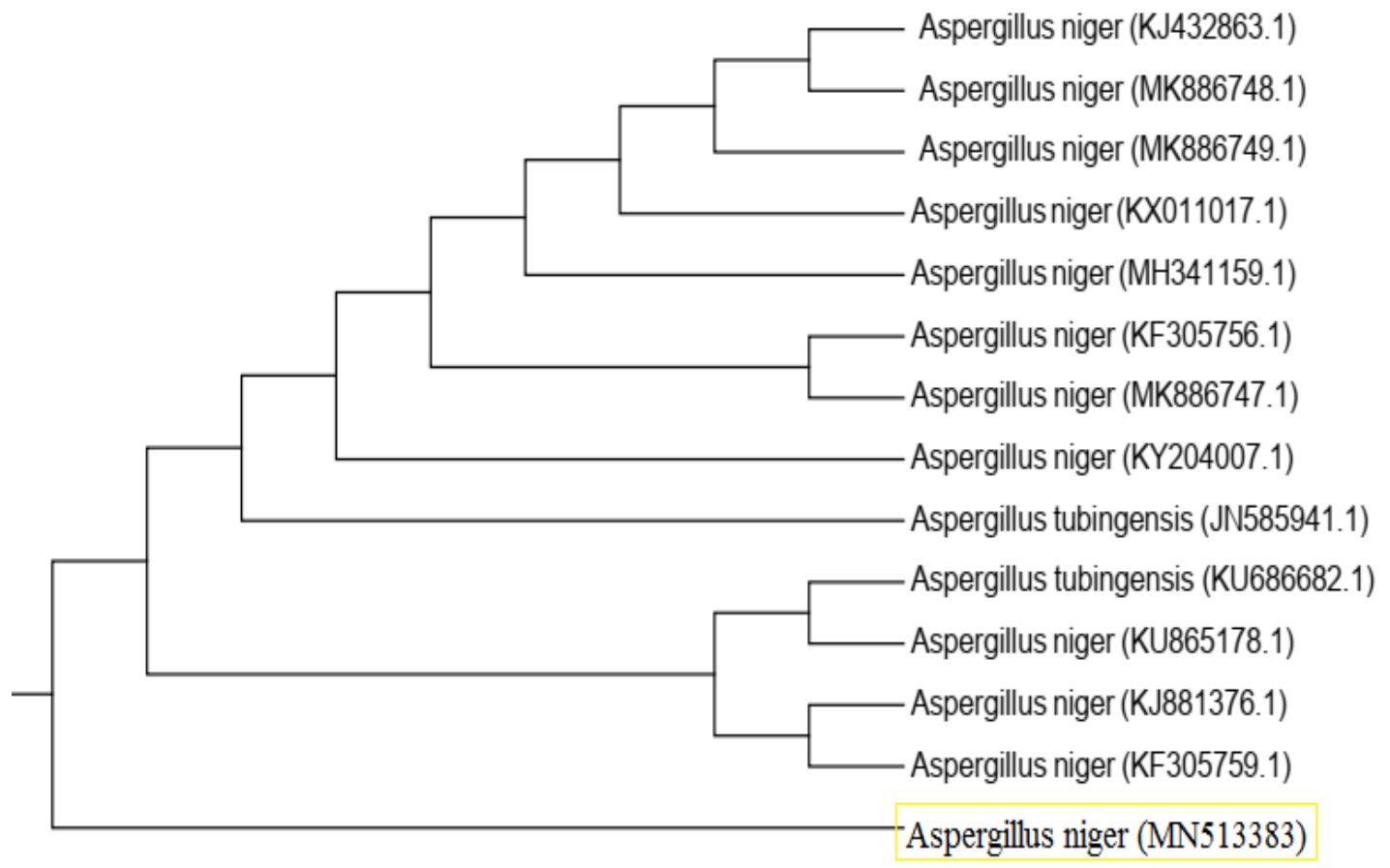

Fig. S2. Phylogenetic analysis tree of Aspergillus niger (MN513383) 


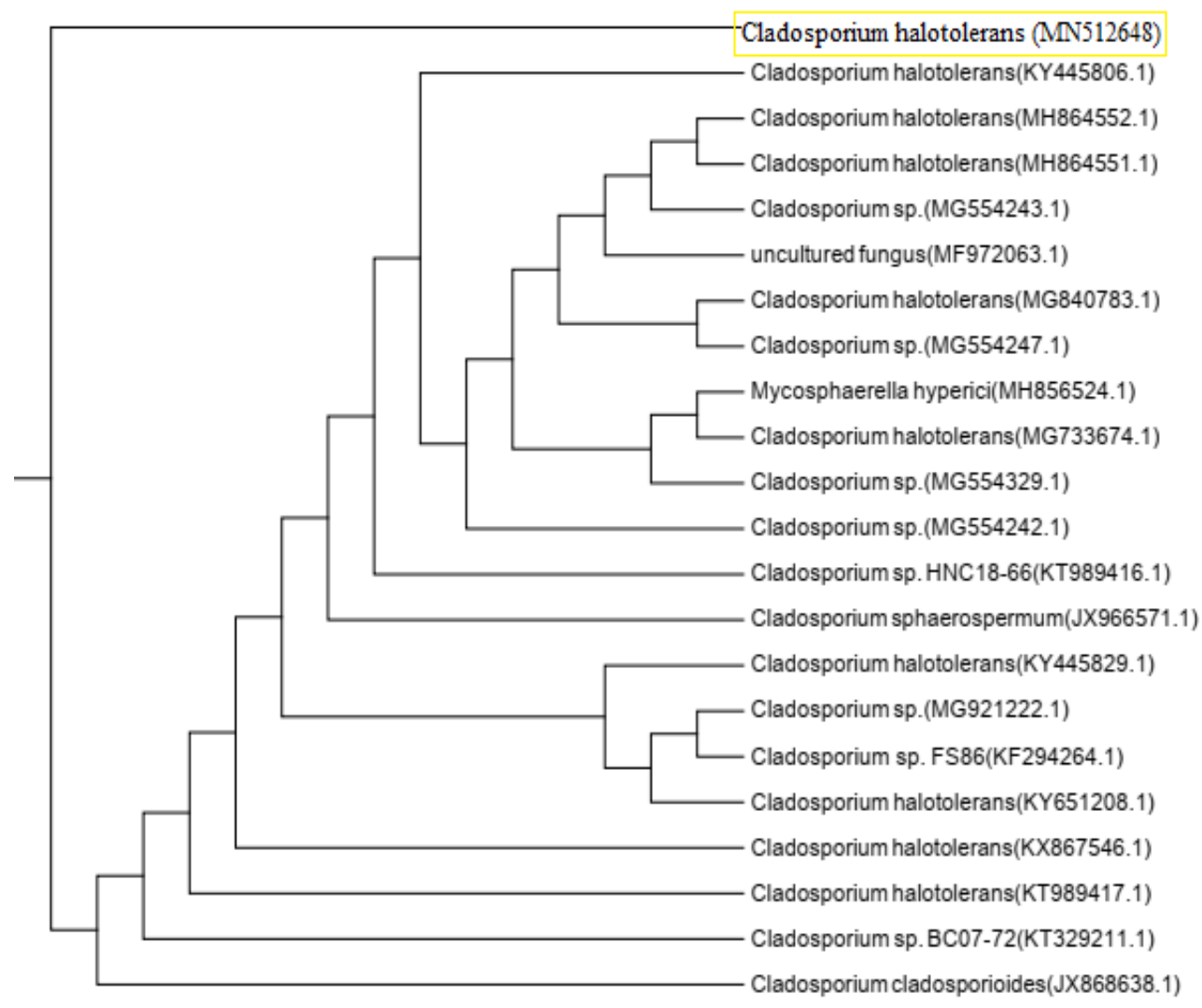

Fig. S3. Phylogenetic analysis tree of Cladosporium halotolerans (MN512648)

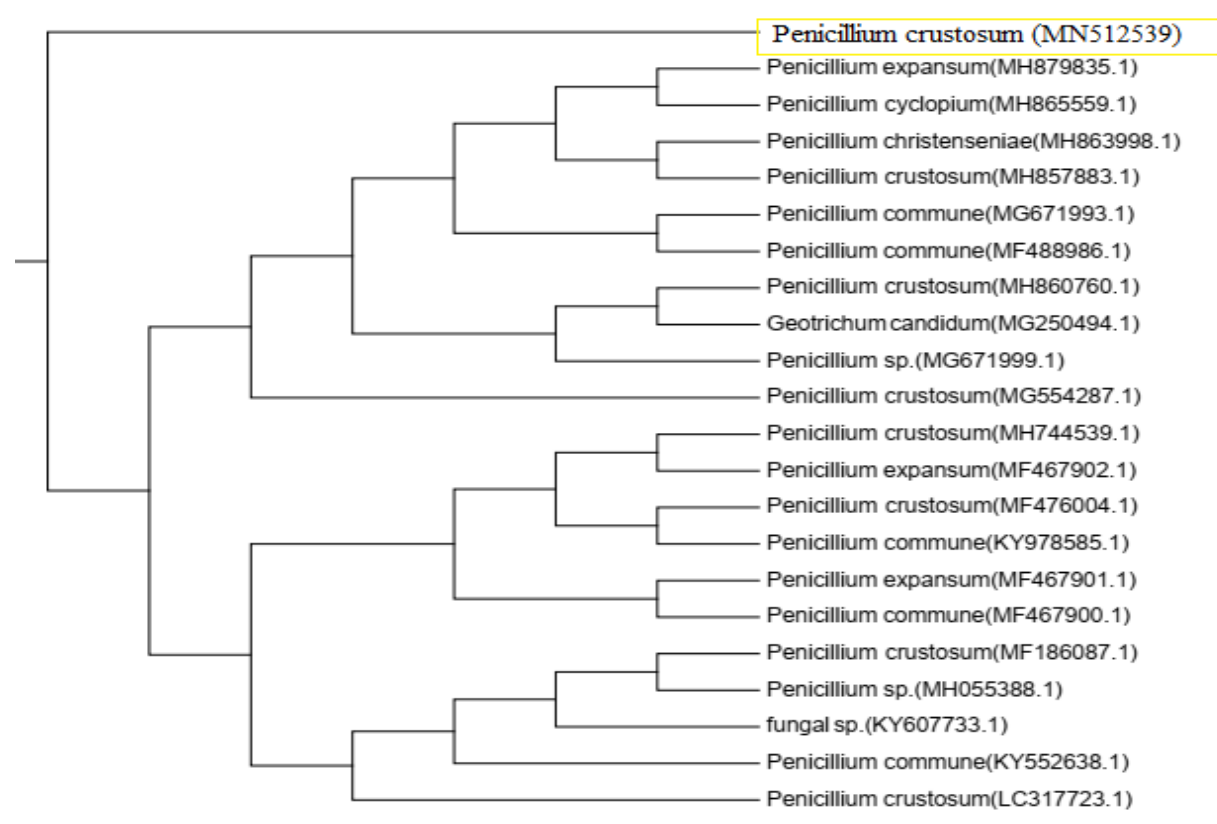

Fig. S4. Phylogenetic analysis tree of Penicillium crustosum (MN512539) 


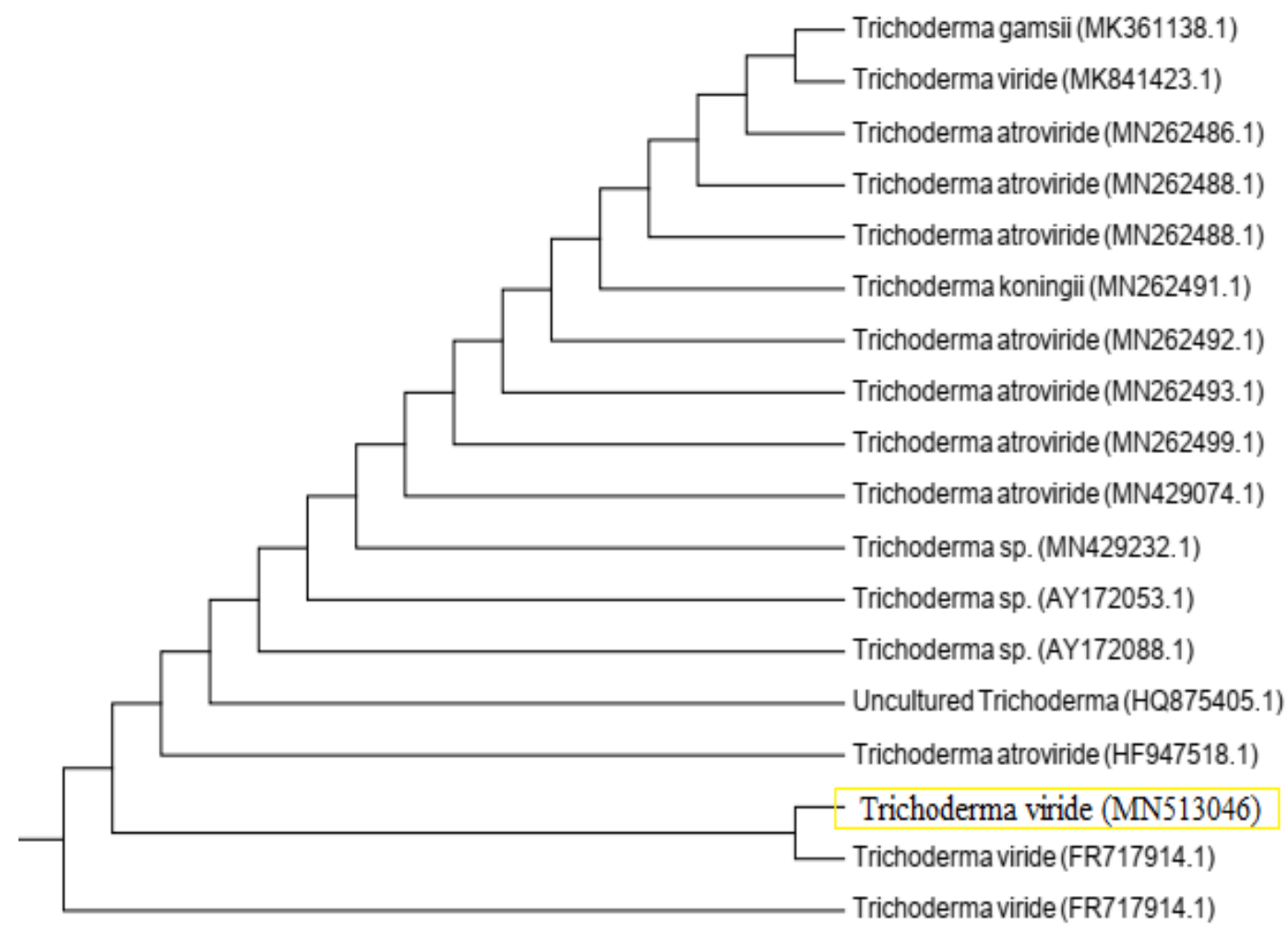

Fig. S5. Phylogenetic analysis tree of Trichoderma viride (MN513046)

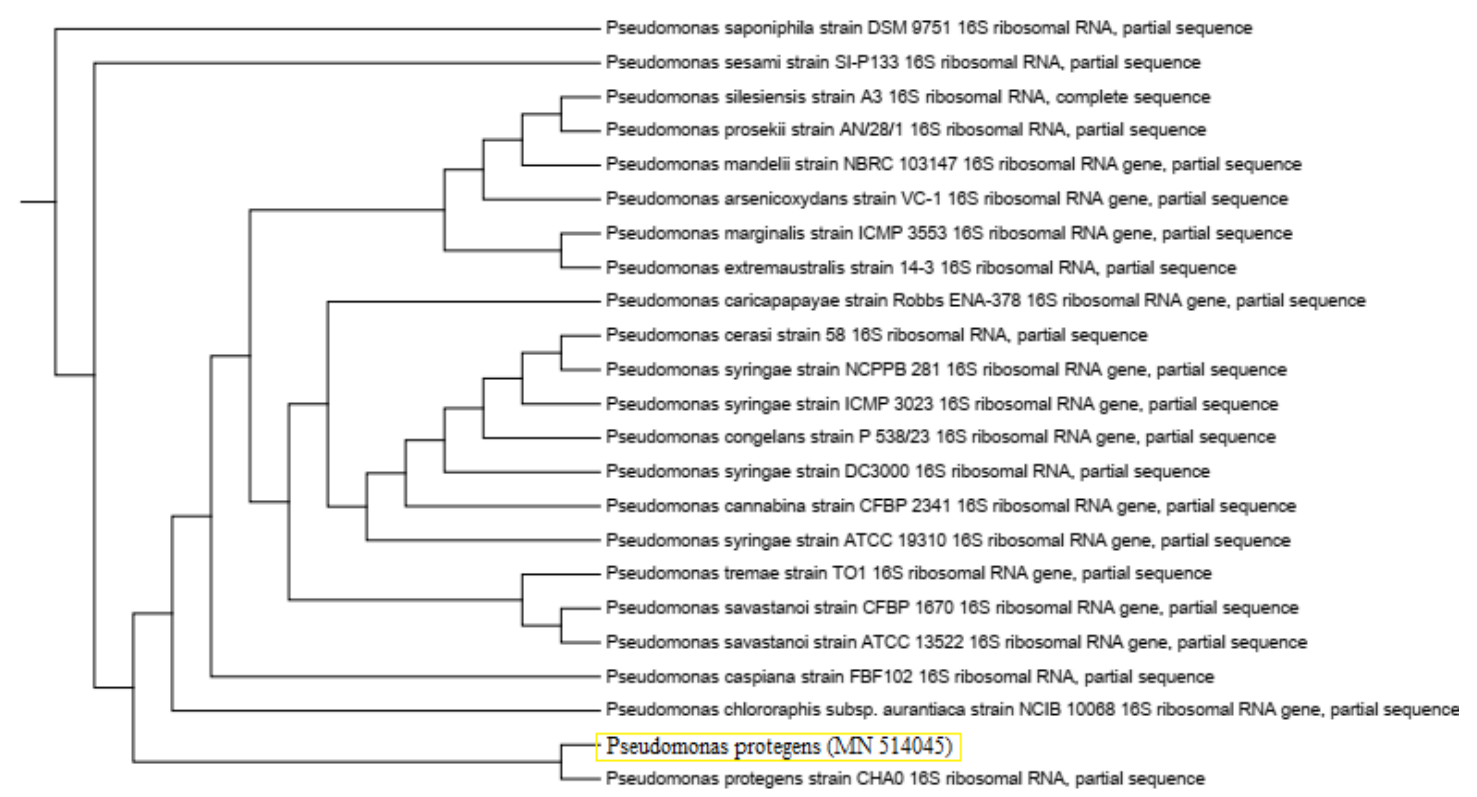

Fig. S6. Phylogenetic analysis tree of Pseudomonas protegens (MN514045) 


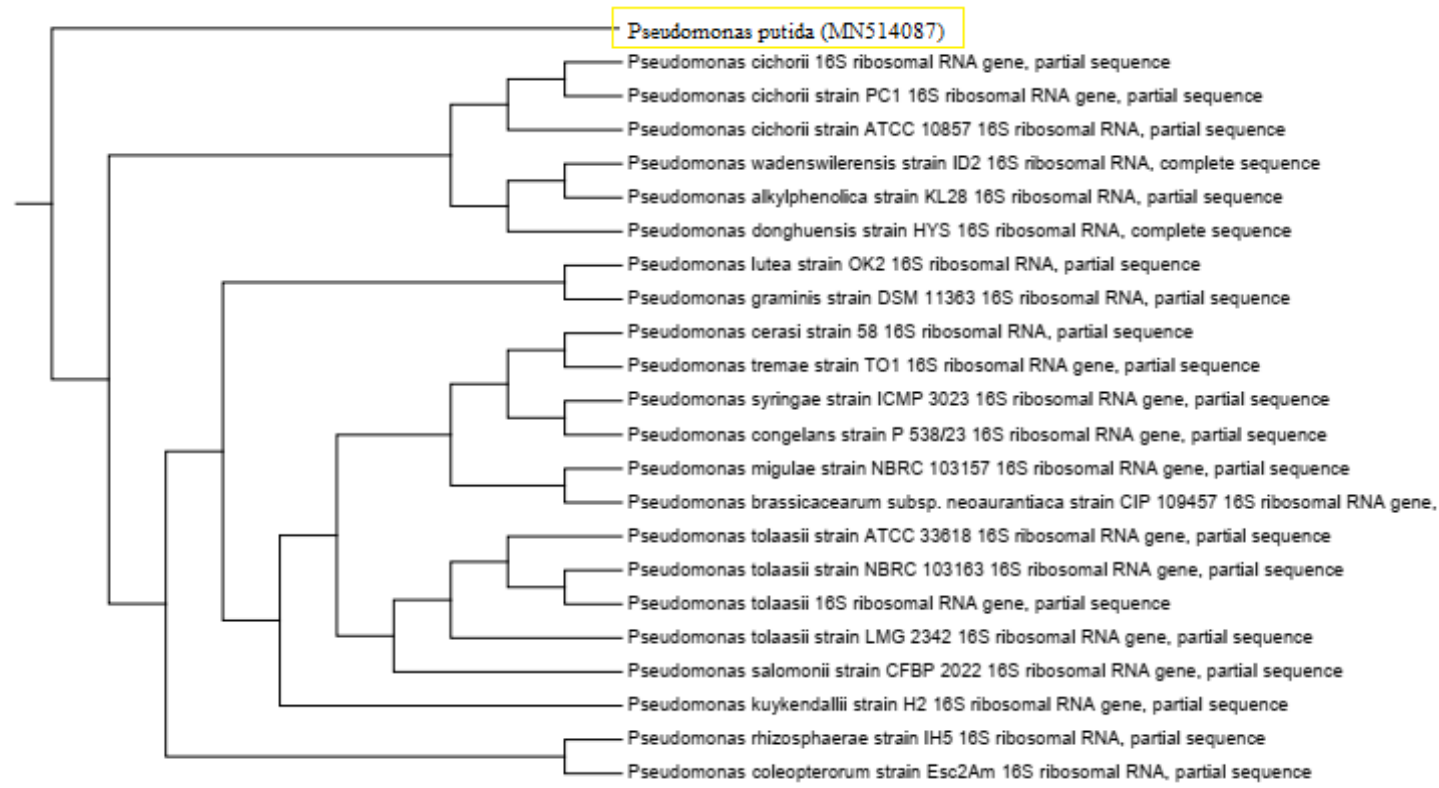

Fig. S7. Phylogenetic analysis tree of Pseudomonas putida (MN514087)

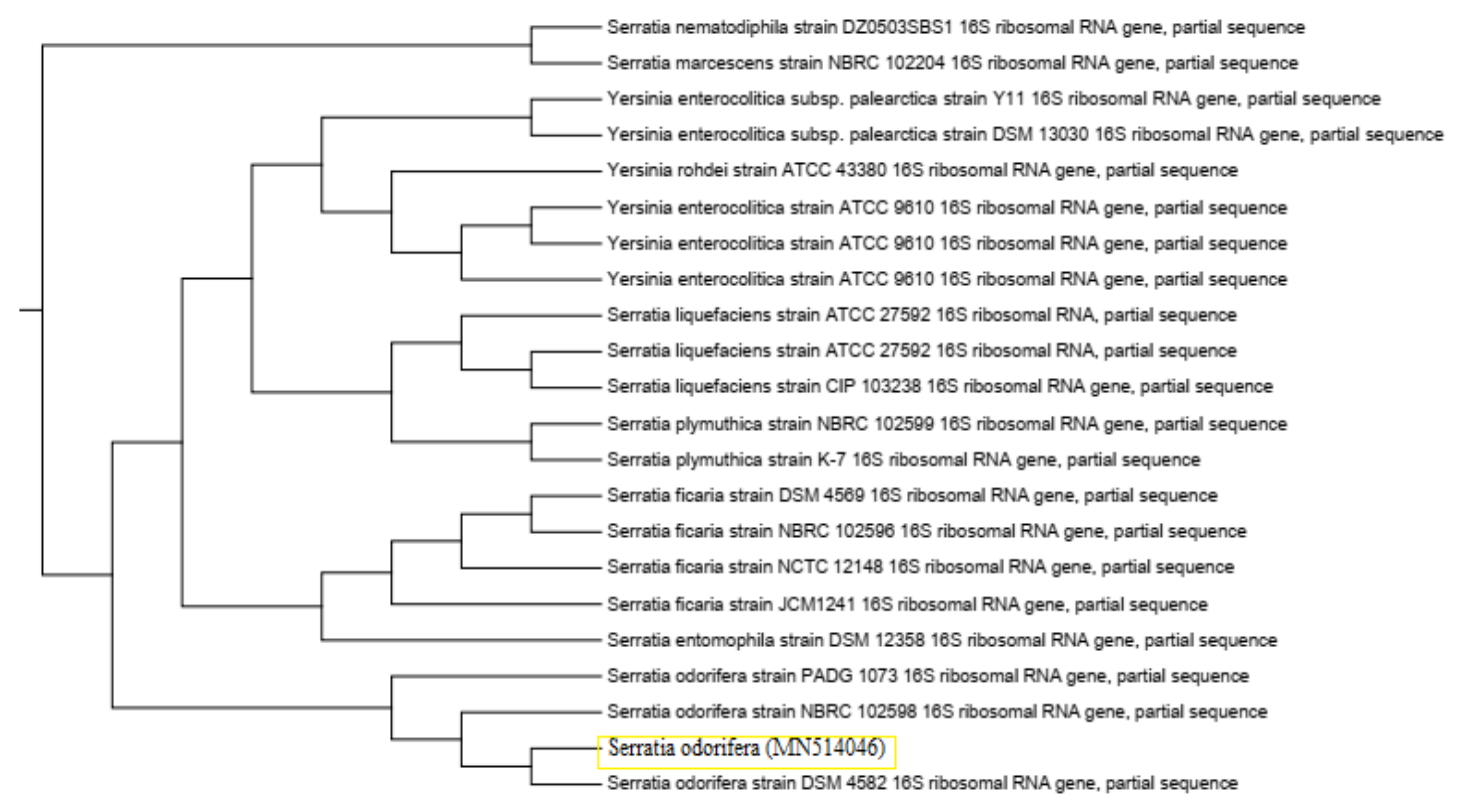

Fig. S8. Phylogenetic analysis tree of Serratia odorifera (MN514046) 